\title{
The Constitution in the Supreme Court: The New Deal, 1931-1940
}

\author{
David P. Currie $\dagger$
}

During the 1920s, over repeated dissents by Justices Holmes, Brandeis, and Stone, the Supreme Court under Chief Justice Taft had been unprecedentedly aggressive in striking down social and economic regulation. ${ }^{1}$ In 1930 , when Taft resigned, President Hoover turned naturally to Charles Evans Hughes, who had distinguished himself not only as governor of New York and as secretary of state but also as associate justice from 1910 until $1916 .{ }^{2}$ In that capacity, Hughes had tended to vote with Holmes to uphold economic regulation, and he had taken a strikingly broad view of the federal commerce power. ${ }^{3}$

The sudden death of Justice Sanford later the same year thus left a Court that could be expected to divide four to four on basic questions of regulatory authority. As the country slid ever deeper into depression, and as legislators and executives turned toward increasingly intrusive regulation as an antidote, the question of Sanford's replacement assumed extraordinary importance.

After liberal senators defeated his first nominee for the crucial ninth seat, ${ }^{4}$ President Hoover appointed Owen J. Roberts of Penn-

$\dagger$ Harry N. Wyatt Professor of Law, University of Chicago. This article is part of a continuing study of the Supreme Court's constitutional decisions since 1789. For earlier installments, see David P. Currie, The Constitution in the Supreme Court: The First Hundred Years 1789-1888 (1985); The Constitution in the Supreme Court: The Protection of Economic Interests, 1889-1910, 52 U. Chi. L. Rev. 324 (1985); The Constitution in the Supreme Court: Full Faith and the Bill of Rights, 1889-1910, 52 U. Chi. L. Rev. 867 (1985); The Constitution in the Supreme Court: 1910-1921, 1985 Duke L. J. 1111; The Constitution in the Supreme Court: 1921-1930, 1986 Duke L. J. 65.

The author wishes to thank Frank Easterbrook and Richard Posner for helpful comments on this paper.

${ }^{1}$ See David P. Currie, The Constitution in the Supreme Court: 1921-1930, 1986 Duke L. J. 65.

2 See David P. Currie, The Constitution in the Supreme Court: 1910-1921, 1985 Duke L. J. 1111; Merlo J. Pusey, Charles Evans Hughes (1951).

${ }^{3}$ See Pusey, 2 Charles Evans Hughes at 660 (cited in note 2), noting progressive opposition to Hughes's appointment as Chief Justice based largely on his having represented corporate clients as an attorney: "The strange thing is that men who claimed to be 'liberals" chose as their target one of the greatest champions of human rights in the current century."

- Judge John J. Parker of the Fourth Circuit was rejected partly because he had fol- 
sylvania. Having spent virtually his entire career in law practice and teaching, Roberts was a largely unknown quantity. ${ }^{5}$ In the story of the Supreme Court during the 1930s, he was to play a very important role. ${ }^{6}$

The story has three chapters and an epilogue. The first chapter is characterized by greater judicial acceptance of social legislation, over the monolithic objections of Justices Van Devanter, McReynolds, Sutherland, and Butler. The path was not straight, but its direction was unmistakable; the laissez-faire majority of the 1920s had become a minority. ${ }^{7}$ Both Hughes and Roberts tended to vote on these matters with Holmes, Brandeis, and Stone; and when the celebrated state court jurist Benjamin Cardozo took Holmes's place in 1932, he tended to take his predecessor's position, too.

Chapter two lasted only two years, from Panama Refining Co. v. Ryan in 1935 to West Coast Hotel Co. v. Parrish in $1937 .{ }^{8}$ In one of the most dramatic periods in its history, the Court began to demolish President Roosevelt's New Deal and appeared to revitalize substantive limitations on state law as well. ${ }^{9}$ None of these decisions, perhaps, was actually inconsistent with what the Court had done before. Several were joined not only by Roberts but by Hughes as well. The most notorious of them all-the "sick chicken" case invalidating the National Industrial Recovery Act-was actually unanimous. ${ }^{10}$ Nevertheless, the division of the Court in other cases left no doubt that both Hughes and (especially) Roberts were less tolerant of the new legislation than their earlier decisions seemed to suggest.

lowed Supreme Court precedent in enforcing a yellow dog contract and partly because of his 1920 statement that the "participation of the Negro in politics is a source of evil and danger to both races and is not desired by the wise men in either race or by the Republican parts of North Carolina." See Carl Brent Swisher, American Constitutional Development 776-79 (1943).

- Roberts had gained some notoriety as special prosecutor in the Teapot Dome cases, however. See Charles A. Leonard, A Search for a Judicial Philosophy: Mr. Justice Roberts and the Constitutional Revolution of 1937 at 8-10 (1971).

- Owen Roberts, wrote Professor Fred Rodell, "was for years the most powerful person in the United States." Nine Men 221 (1955).

' See Robert G. McCloskey, The American Supreme Court 163-64 (1960); Edward S. Corwin, The Twilight of the Supreme Court 44-45 (1934).

- 293 U.S. 388 (1935); 300 U.S. 379 (1937).

- See Benjamin F. Wright, The Growth of American Constitutional Law ch. 9 (1942); McCloskey, The American Supreme Court at 165-68 (cited in note 7): "for two busy terms the Court waged what is surely the most ambitious dragon-fight in its long and checkered history."

10 A.L.A. Schechter Poultry Corp. v. United States, 295 U.S. 495 (1935). 
Chapter three records the famous "switch in time," the remarkable reversal beginning with the upholding of a minimum wage law in Parrish and resulting in the virtual abandonment not only of the judicially created doctrine of substantive due process but also of the Constitution's own basic principle of limited federal power. ${ }^{11}$ These revolutionary changes were cemented by the replacement of three of the activist old guard (and of Brandeis and Cardozo) by representatives of the new order: Hugo Black, Stanley Reed, Felix Frankfurter, William O. Douglas, and Frank Murphy. ${ }^{12}$ But that was just icing on the cake; the essential change had occurred before any new appointments were made.

These three chapters in the destruction of the old order are the subject of the present paper. The epilogue-a legacy of deci-

11 See McCloskey, The American Supreme Court at 175-87 (cited in note 7); Wright, The Growth of American Constitutional Law at ch. 10 (cited in note 9); Edward S. Corwin, Constitutional Revolution, Ltd. 64-79 (1941).

12

Justices of the Supreme Court During The Time of

Chief Justice Hughes (1930-1941)

\begin{tabular}{rllllll}
\hline \hline 1930 & 1932 & 1934 & 1936 & 1938 & 1940 \\
\hline
\end{tabular}

Oliver Wendell Holmes, Jr.

Willis Van Devanter

James C. McReynolds

Louis D. Brandeis

George Sutherland

Pierce Butler

Harlan F. Stone

Charles Evans Hughes

Owen J. Roberts

Benjamin N. Cardozo

Hugo L. Black

Stanley F. Reed

Felix Frankfurter

William 0. Douglas

Frank Murphy
(1902-1932)

(1910-1937)

(1914-1941)

(1916-1939)

(1922-1938)

(1922-1939)

(1925-1946)

(1930-1941)

(1930-1945)

(1932-1938)

(1937-1971)

(1938-1957)

(1939-1962)

(1939-1975)

(1940-1949)

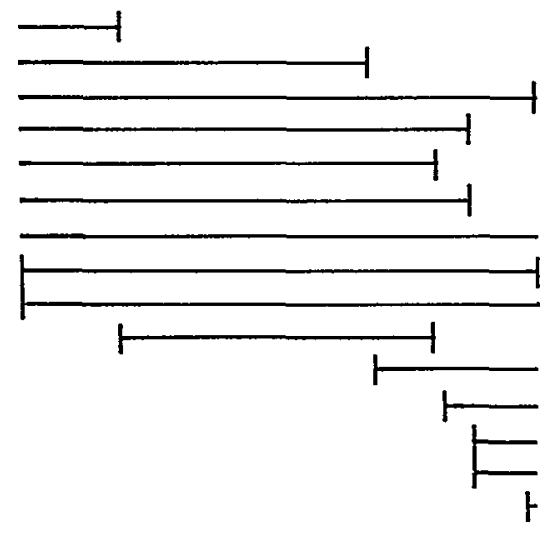

Source: Adapted from Gerald Gunther, Constitutional Law, app. B at B-4 to B-6 (11th ed. 1985).

Biographies of these Justices include Pusey, Charles Evans Hughes (cited in note 2); Leonard, A Search for a Judicial Philosophy (cited in note 5); George S. Hellman, Benjamin N. Cardozo: American Judge (1940); Alpheus Thomas Mason, Brandeis: A Free Man's Life (1946); Joel Francis Paschal, Mr. Justice Sutherland: A Man Against the State (1951); Alpheus Thomas Mason, Harlan Fiske Stone: Pillar of the Law (1956); Gerald T. Dunne, Hugo Black and the Judicial Revolution (1977); Helen Shirley Thomas, Felix Frankfurter: Scholar on the Bench (1960); J. Woodford Howard, Mr. Justice Murphy: A Political Biography (1968). 
sions expanding civil rights and liberties that foreshadowed the agenda of the future-will be considered in a subsequent article.

\section{The Dawn of a New Day?}

\section{A. Due Process and Equal Protection}

During the 1920s the Court had struck down price regulation of theater admissions, employment agencies, and gasoline dealers, strengthening the traditional view that government had no legitimate interest in rectifying the effects of unequal bargaining power except in a narrowly defined category of businesses "affected with a public interest."1s Under Chief Justice Hughes, the Court lost little time in taking a different view.

1. Insurance commissions and chain-store taxes. The first hint of a more tolerant approach came just a few months after the new appointments when, in O'Gorman \& Young, Inc. v. Hartford Fire Ins. Co., the Court upheld a state law forbidding the payment of excessive or disuniform commissions to fire insurance agents. ${ }^{14}$ As Justice Brandeis emphasized in a brief opinion for the majority, the Court had already allowed states to regulate the rates charged to policyholders because the insurance business was affected with a public interest, and the amounts paid to agents had an obvious effect on those rates. ${ }^{18}$ Thus on the surface the case seemed easy; even Van Devanter, who had dissented from the earlier decision, did not deny that insurance was affected with a public interest. ${ }^{18}$

Justices Van Devanter, McReynolds, Sutherland, and Butler nevertheless dissented, arguing that the sole effect of the statute as construed was to prevent paying agents at different rates, not to limit their compensation. Thus, "the restrictions have no immediate or necessary relation" to the cost of insurance; "so far as we

$1 s$ Tyson \& Brother v. Banton, 273 U.S. 418 (1927) (theater admissions); Ribnik v. McBride, 277 U.S. 350 (1928) (employment agencies); Williams v. Standard Oil Co., 278 U.S. 235 (1929) (gasoline dealers). See also Currie, 1986 Duke L. J. at 76-79 (cited in note 1). For the origins of the public interest requirement, see David P. Currie, The Constitution in the Supreme Court: The First Hundred Years 1789-1888 at 370-73 (1985), discussing Munn v. Illinois, 94 U.S. 113 (1877). For the narrow conception of legitimate governmental ends reflected in the Taft Court decisions, see David P. Currie, The Constitution in the Supreme Court: The Protection of Economic Interests, 1889-1910, 52 U. Chi. L. Rev. 324, 378-82 (1985), discussing Lochner v. New York, 198 U.S 45 (1905); Currie, 1985 Duke L. J. at 112931 (cited in note 2).

14282 U.S. 251 (1931).

1s Id. at 257, citing German Alliance Ins. Co. v. Lewis, 233 U.S. 389 (1914), noted in Currie, 1985 Duke L. J. at 1130 n.96 (cited in note 2).

${ }^{16} 282$ U.S. at 266 (Van Devanter, McReynolds, Sutherland, and Butler, dissenting). 
can see, this legislation will afford no protection to those who wish to insure." $" 17$

The decisive difference between the majority and the dissent seemed to concern the appropriate level of scrutiny of the relation between means and ends, and it was brought home by sharply contrasting views as to the burden of proof. While the dissenters insisted that the party seeking to sustain the law must show "special circumstances sufficient to indicate the necessity" for the specific means chosen, Brandeis concluded that "the presumption of constitutionality must prevail in the absence of some factual foundation of record for overthrowing the statute."18 It was this attitude, more than the result in the particular case, that seemed to augur an easier time for regulation in the years to come. ${ }^{10}$

An equal protection decision rendered later in the same term lent additional force to this expectation. In State Board of Tax Commissioners $v$. Jackson, over the same four dissents, Justice Roberts wrote to uphold a license tax that discriminated against chain stores. ${ }^{20}$ Arguing that the advantages attributed to multiple stores actually depended upon the size of the business, Sutherland's dissent tellingly invoked a recent decision invalidating a taxicab tax that had discriminated against corporations. ${ }^{23}$ Roberts, whose tedious opinion consisted largely of poorly integrated summaries of earlier decisions, went to some lengths to show that no individual store enjoyed all the advantages of a chain. ${ }^{22}$ If Roberts seemed more concerned to show that there was an actual justification for the challenged measure than Brandeis had been in the in-

17282 U.S. at 269-70. The dissenters also argued that the law might actually increase costs: "in order to operate at all . . . [in some geographic areas], the insurer may find it necessary to pay agents much more than prudent management would require [at other localities], and beyond the real value of their services at such [other] places." Unless the resulting fee was itself illegal, the nondiscrimination provision would require payment of an inflated fee throughout the state. Id. at 270.

${ }^{18}$ Id. at 269, 257-58. Brandeis's approach seems more in accord with Justice Chase's original perception. See Hylton v. United States, 3 U.S. 171, 174 (1796): "it is unnecessary ... for me to determine, whether this court, constitutionally possesses the power to declare an act of congress void, on the ground of its being made contrary to . . the constitution; but if the court have such power, I am free to declare, that I will never exercise it, but in a very clear case." See also Currie, First Hundred Years at 33 (cited in note 13).

10 On the day O'Gorman was decided, wrote Walton Hamilton, "the views of Brandeis" respecting judicial review in general "became "the opinion of the court and a new chapter in judicial history began to be written.' " Walton H. Hamilton, The Jurist's Art, 31 Colum. L. Rev. 1073, 1073 (1931).

${ }^{20} 283$ U.S. 527 (1931).

${ }^{22}$ Id. at 546-50, citing Quaker City Cab Co. v. Pennsylvania, 277 U.S. 389 (1928).

22283 U.S. at $534-36$. 
surance case, he also appeared quite willing to find one.

2. Ice monopolies and milk prices. That the millennium had not yet arrived was rudely demonstrated the following term when both Hughes and Roberts joined Justice Sutherland's opinion in New State Ice Co. v. Liebmann, striking down a law limiting entry into the ice business. ${ }^{23}$ Unlike cotton ginning, where the Court had recognized the validity of a similar restriction, ${ }^{24}$ the ice business was not, in the majority's view, "charged with a public use."2s Brandeis's monumental dissent, joined by Stone, coupled judicial restraint with condemnation of wasteful competition, reminded the reader how far the Court had departed from the Slaughter-House Cases, ${ }^{28}$ and closed with the famous description of the states as "laborator[ies]" able to "try novel social and economic experiments without risk to the rest of the country."27

Liebmann's echo of the past was drowned out in 1934 by Justice Roberts's celebrated fortissimo in Nebbia $v$. New York, upholding minimum milk prices. ${ }^{28}$ The notion that price and entry regulations were permissible only in certain businesses affected with a public interest, Roberts insisted, had been based upon a misunderstanding of the decision sustaining rate regulation in Munn v. Illinois. ${ }^{29}$ "The phrase 'affected with a public interest' can, in the nature of things, mean no more than that an industry, for adequate reason, is subject to control for the public good." A court's task, he concluded, was "to determine in each case whether circumstances vindicate the challenged regulation as a reasonable exertion of governmental authority or condemn it as arbitrary or discriminatory." 30 This was what Brandeis had said in dissenting

23 285 U.S. 262 (1932). See Pendleton Howard, The Supreme Court and State Action Challenged Under the Fourteenth Amendment, 1931-1932, 81 U. Pa. L. Rev. 505, 514 (1933), citing Liebmann and intervening decisions invalidating state taxes as casting "considerable doubt" on the thesis that O'Gorman "was portentous of a more tolerant attitude toward state legislative action challenged under the Fourteenth Amendment."

24 Frost v. Corporation Commission, 278 U.S. 515 (1929).

28285 U.S. at 277.

1683 U.S 36 (1873) (holding that Louisiana statute giving partial monopoly of the slaughtering business to one company did not violate the fourteenth amendment).

${ }_{27} 285$ U.S. at 285, 292, 303, 311. Holmes had resigned; Cardozo, just appointed, did not participate. Brandeis attacked the requirement that the regulated business be "affected with a public interest" as resting upon "historical error": "the true principle is that the State's power extends to every regulation of any business reasonably required and appropriate for the public protection." Id. at 302-03. For criticism of the notion of "wasteful" competition, see Richard A. Posner, Economic Analysis of Law 590-92 (3d ed. 1986).

28 291 U.S. 502 (1934).

2994 U.S. 113 (1877).

so 291 U.S. at 536. 
from Liebmann, which Roberts did not mention, and it left the reader wondering how Roberts and Hughes could have gone along with the contrary decision in that case..$^{31}$

Freed from the necessity to demonstrate that the milk business was affected with a public interest, Roberts was within easy reach of his goal. Reciting legislative findings as to the harmful effects of unrestricted price cutting, he found the challenged measure not "without relation" to the legitimate "purpose to prevent ruthless competition from destroying the wholesale price structure on which the farmer depends for his livelihood, and the community for an assured supply of milk." McReynolds and his three soulmates predictably added an anguished and rambling dissent. ${ }^{32}$ Economic due process was unmistakably in retreat; both Hughes and Roberts had come down firmly on the side of tolerance for economic legislation. ${ }^{33}$

\section{B. The Contract Clause}

Even more dramatic than what the new justices did to substantive due process in Nebbia was what they had done to the contract clause just a few months earlier in Home Building \& Loan Ass'n v. Blaisdell. ${ }^{34}$ At the depth of the depression, Minnesota had passed a law authorizing up to two years' extension of the redemption period upon foreclosure of preexisting mortgages. ${ }^{35}$ As Sutherland wrote for the usual four dissenters in one of his most powerful opinions, debt extensions in economic crises had been among the specific evils the clause was designed to prevent, and the Court had repeatedly struck them down since Bronson $v$. Kinzie nearly a century before. ${ }^{38}$ Yet the majority upheld the law in a landmark opinion by Chief Justice Hughes specifically declaring the original un-

s1 285 U.S. at 285 . Hughes later told his biographer that although he had considered Liebmann a close case, he thought it reconcilable with Nebbia because in the latter case no one had been denied the right to sell milk-i.e., the restriction was less intrusive. Roberts "is said to have paced the floor . . . until the early morning hours" before deciding how to vote in Nebbia. See Pusey, 2 Charles Evans Hughes at 700 (cited in note 2).

32291 U.S. at 530 (majority opinion of Roberts), 539-59 (dissent of McReynolds).

${ }^{33}$ See Thomas Raeburn White, Constitutional Protection of Liberty of Contract: Does It Still Exist?, 83 U. Pa. L. Rev. 425, 440 (1935), lamenting after Nebbia that "the Supreme Court has in effect surrendered its power to declare void acts of legislature on the ground that they infringe liberty of contract."

34290 U.S. 398 (1934).

ss The statute authorized a court to extend the then existing one-year period of redemption as necessary.

${ }^{36} 290$ U.S. at 448, 453-71, citing, among other cases, Bronson v. Kinzie, 42 U.S. 311 (1843). See also Currie, First Hundred Years at 211-13 (cited in note 13). 
derstanding irrelevant: "If by the statement that what the Constitution meant at the time of its adoption it means to-day, it is intended to say that the great clauses of the Constitution must be confined to the interpretation which the framers, with the conditions and outlook of their time, would have placed upon them, the statement carries its own refutation."37

Hughes demonstrated at some length that the Court had often permitted modifications of contract remedies that did not alter the obligation itself. ${ }^{38} \mathrm{He}$ nowhere said an extension of the redemption period went only to the remedy, and Bronson had held it did not. Bronson had also confirmed that even remedial changes were forbidden if they " "materially . . . impair[ed] the rights and interests of the owner," "as the extension of time seemed clearly to do. ${ }^{39}$

Apart from the matter of remedies, Hughes hastened to add, "the State also continues to possess authority to safeguard the vital interests of its people. . . . [T] he reservation of essential attributes of sovereign power is . . . read into contracts as a postulate of the legal order." "As evidence, he cited decisions holding that public contracts implicitly reserved the power of condemnation, ${ }^{41}$ that states could not bargain away the power to forbid such arguably obnoxious activities as lotteries, ${ }^{\mathbf{} 2}$ and, most pertinently, that private contracts were subject to later exercises of the police power. ${ }^{43}$

Nobody had objected when this last proposition was asserted in an obscure 1905 case involving a promise not to obstruct a creek, and Blaisdell seemed to show just how sweeping that con-

s7 290 U.S. at 442-43. Predictably, the chief justice took refuge in Marshall's oracular dictum that " 'it is a constitution we are expounding." " 290 U.S. at 443, quoting McCulloch v. Maryland, 17 U.S. 316, 407 (1819). For academic approval of the notion that original meaning is irrelevant, see Jacobus tenBroek, Use by the United States Supreme Court of Extrinsic Aids in Constitutional Construction (part 5), 27 Cal. L. Rev. 399 (1939). But see Richard A. Epstein, Toward a Revitalization of the Contract Clause, 51 U. Chi. L. Rev. 703, 735 (1984): "This passage contains some of the most misguided thinking on constitutional interpretation imaginable." Hughes's further suggestion that the framers might have approved of the decision had they been aware of "the conditions of the later day," 290 U.S. at 443, was hardly credible in light of Sutherland's demonstration that the clause had been adopted precisely to prevent debtor relief in times of economic crisis.

ss 290 U.S. at $429-34$.

s9 Bronson, 42 U.S. at 315, quoting Green v. Biddle, 21 U.S. 1,17 (1823). Unlike the extension provision in Bronson, the law in Blaisdell required payment of a reasonable rent during the period of extension. Nevertheless, as Sutherland observed, it deprived the mortgagee of the significant rights of occupancy and sale. 290 U.S. at 480.

10290 U.S. at 434-35.

1 Id. at 435-38, citing, for example, West River Bridge Co. v. Dix, 47 U.S. 507 (1848).

12 Stone v. Mississippi, 101 U.S. 814 (1880).

is Manigault v. Springs, 199 U.S. 473 (1905). See also Currie, First Hundred Years at 213-15 (cited in note 13); Currie, 52 U. Chi. L. Rev. at 334-35 (cited in note 13). 
clusion had been. ${ }^{44}$ One might have argued there was a difference between a contract to commit murder and one for foreclosure of a mortgage, but Hughes flatly rejected it, and even the earlier decision was arguably on the wrong side of the line. ${ }^{45}$ Subjecting private contracts to the police power seemed to reduce the contract clause to the equivalent of substantive due process. ${ }^{46}$

The upshot seemed to be that the mortgage moratorium law was valid, despite its detrimental impact on the obligation, if it was "reasonable." 47 If this was the question, the answer was easy: the relief of debtors in an economic emergency was a legitimate end and the moratorium a reasonable means of attaining it. "If it be determined, as it must be, that the contract clause is not an absolute and utterly unqualified restriction of the State's protective power, this legislation is clearly so reasonable as to be within the legislative competency."48

Precedent may have pointed the way to this conclusion, but the Court had never before said quite so blatantly that the prohibition of "any . . . law impairing the obligation of contracts" forbade only unreasonable impairments. ${ }^{48}$ One is reminded of the

4t See Robert L. Hale, The Supreme Court and the Contract Clause: II, 57 Harv. L. Rev. 621, 671-74 (1944).

45 See Blaisdell, 290 U.S. at 438-39, dismissing the argument that "state power may be addressed directly to the prevention of the enforcement of contracts only when these are of a sort which the legislature in its discretion may denounce as being in themselves hostile to public morals, or public health, safety or welfare, or where the prohibition is merely of injurious practices." Sutherland's manful effort to tie the police power principle to the established doctrine of implied conditions excusing performance on the ground of supervening illegality fell short of explaining all the precedents. See id. at 475-78 (Sutherland, dissenting); Benjamin Fletcher Wright, Jr., The Contract Clause of the Constitution 211-12 (1938) (reading precedents to subject contract rights between private persons to police power only in cases of "unusual public importance").

t6 See Robert L. Hale, The Supreme Court and the Contract Clause: III, 57 Harv. L. Rev. 852, 890-91 (1944) ("there is at least a tendency for the contract clause and the due process clause to coalesce"). Holmes had pretty well said as much in 1921 in upholding over four dissents a state law extending housing leases: "contracts are made subject to this exercise of the power of the State when otherwise justifiable, as we have held this [under the due process clause] to be." Marcus Brown Holding Co. v. Feldman, 256 U.S. 170, 198 (1921). Sutherland properly made no serious effort to distinguish this decision, accurately observing that the contract clause question there had "received little, if any, more than casual consideration." 290 U.S. at 478-79. Hughes naturally gave it prominent billing. Id. at 440-42.

47 See 290 U.S. at 444: "The principle of this development is . . that the reservation of reasonable exercise of the protective power of the State is read into all contracts."

4s Id. at 447.

40 See McCloskey, The American Supreme Court at 164 (cited in note 7): "The idea appeared to be that the states could now violate the contract clause so long as they were 'reasonable' about it." See also Wright, The Contract Clause at 112 (cited in note 45): "taken in connection with other decisions ... interpreting . . . the prohibition . . . [of the contract] clause, . . . [Blaisdell] appears as merely another step, and not necessarily a long 
scene from Animal Farm in which reexamination of a provision that "[n]o animal shall drink alcohol" reveals it to outlaw drinking only "to excess."

To narrow the text of a constitutional provision on the basis of its history has a long and respectable pedigree based upon the premise that the framers' words are only a partial guide to their command. ${ }^{51}$ To do so in the teeth of that history seems to give a most unhappy connotation to Hughes's earlier remark that "the Constitution is what the judges say it is."

\section{Federal Powers}

Even in Chief Justice Taft's days, the Court had read Congress's power to regulate interstate commerce rather broadly, ${ }^{\mathbf{6 3}}$ and in the early 1930 s it continued to do so. In Texas \& N.O. R.R. v. Brotherhood of Railway \& S.S. Clerks, in 1930, the Court upheld a provision of the Railway Labor Act protecting the right of rail

one, in the change of that prohibition from an absolute one to a reasonable one."

so "[A] few days later Muriel, reading over the Seven Commandments to herself, noticed that there was yet another of them which the animals had remembered wrong. They had thought the Fifth Commandment was 'No animal shall drink alcohol,' but there were two words that they had forgotten. Actually the Commandment read: 'No animal shall drink alcohol to excess.' " George Orwell, Animal Farm 120 (illus. ed. 1954) (emphasis in original).

${ }^{31}$ See Currie, First Hundred Years at 14-20, $41-49$ (cited in note 13), discussing Chisholm v. Georgia, 2 U.S. 419 (1793), and Calder v. Bull, 3 U.S. 386 (1798).

s2 See Pusey, 1 Charles Evans Hughes at 204 (cited in note 2), quoting the 1907 speech in which Hughes made this remark and indignantly rejecting the suggestion that Hughes had meant to "expose[] the solemn function of judging as a sort of humbuggery."

Contemporaneous decisions respecting intergovernmental immunities also reflected a lenient tendency. See, e.g., Educational Films Corp. v. Ward, 282 U.S. 379, 391 (1931) (Stone, over the expected dissents of Sutherland, Van Devanter, and Butler) (upholding a state corporation tax whose measure included copyright royalties despite an earlier decision invalidating state taxes laid directly upon patent royalties) (Long v. Rockwood, 277 U.S. 142 (1928)) and despite McCallen Co. v. Massachusetts, 279 U.S. 620 (1929) (which seemed to reject precedents allowing a state to measure taxes by income it could not tax as such)); Fox Film Corp. v. Doyal, 286 U.S. 123 (1932) (Hughes) (unanimously overruling Long v. Rockwood in holding that, like land granted to a private party by the United States, copyright royalties themselves were subject to state taxation). The Court demonstrated that it was not yet prepared to make a very great shift in this field, however, by reaffirming that Congress could tax neither sales to local governments, Indian Motocycle Co. v. United States, 283 U.S. 570 (1931) (Van Devanter, over dissents by Stone and Brandeis, and with Holmes acquiescing solely on the basis of precedent), nor the income from a state oil lease, Burnet $v$. Coronado Oil \& Gas Co., 285 U.S. 393 (1932) (McReynolds, over dissents by Stone, Brandeis, Roberts, and Cardozo). Brandeis's opinion in Coronado Oil contains a careful argument for limiting stare decisis in cases involving application of the Constitution to particular facts. 285 U.S. at 405-13. For detailed and penetrating analysis of these and later decisions in this field, see Thomas Reed Powell, Vagaries and Varieties in Constitutional Interpretation 118-41(1956).

${ }^{53}$ See Currie, 1986 Duke L. J. at 112-14 (cited in note 1). 
workers to choose bargaining representatives, reasoning that "Congress may facilitate the amicable settlement of disputes which threaten the service of the necessary agencies of interstate transportation." 54 Despite the contrary thrust of the twenty-year-old decision in Adair $v$. United States, ${ }^{35}$ which had struck down a ban on "yellow dog" contracts in the face of a similar argument, no one dissented. ${ }^{\circ 8}$ The next year, in Arizona $v$. California, the Court held that an act providing for construction of Boulder Dam fell within the power to "regulate commerce ... among the several states," although it involved spending rather than regulation and despite a plausible argument that the dam would impair rather than promote navigation. $^{\mathrm{sz}}$

The most significant relaxation of constitutional obstacles to the modern administrative state, however, came in Chief Justice Hughes's 1932 opinion in Crowell v. Benson. The Longshoremen's and Harbor Workers' Compensation Act, enacted in 1927 to fill gaps in compensation for injured workers created by decisions limiting state authority over maritime matters, empowered a federal administrative agency to adjudicate maritime workers' compensation claims, authorizing the courts to set aside agency orders "not in accordance with law." "Apart from cases involving constitutional rights," wrote Hughes, "the Act contemplates that, as to questions of fact . . . the findings of the deputy commissioner, supported by the evidence and within the scope of his authority, shall be final." "s8

Properly disdaining reliance on precedent, ${ }^{58}$ the Court found this scheme consistent with article III's command that federal judicial power be vested in judges with life tenure and irreducible salary. "[T] $]$ here is no requirement that . . . all determinations of

s4 281 U.S. 548, 570 (1930) (Hughes).

ss 208 U.S. 161 (1908) (Harlan). See Currie, 52 U. Chi. L. Rev. at 352-53 (cited in note 13).

Bs McReynolds did not participate. Texas \& N.O. R.R., 281 U.S. at 571. See also Powell, Vagaries and Varieties at 78 (cited in note 52), arguing that this decision and NLRB v. Jones \& Laughlin Steel Corp., 301 U.S. 1 (1937), "clearly annul Mr. Justice Harlan's absurd commerce clause point in the Adair case."

${ }^{87} 283$ U.S. 423 (1931) (Brandeis). McReynolds alone dissented, id. at 464, arguing only that the case should not be disposed of on a motion to dismiss. See Russell Denison Niles, Arizona v. California, 10 N.Y.U. L. Q. Rev. 188, 194-201 (1932).

s8 285 U.S. $22,39-40,44,46$ (1932).

so Earlier cases, as Hughes noted, had allowed Congress to vest civilian adjudicatory authority within the states in non-article III tribunals only when there was no constitutional right to judicial proceedings of any kind, as in the payment of government obligations. See id. at 50-51, discussing Ex parte Bakelite Corp., 279 U.S. 438 (1929); Currie, 1986 Duke L. J. at 131-34 (cited in note 1). 
fact . . . be made by judges"; juries and masters made them all the time. "[T] he reservation of full authority to the court to deal with matters of law provides for the appropriate exercise of the judicial function in this class of cases."

In the next section of the opinion, in which he concluded that "fundamental or 'jurisdictional" fact findings had to be reviewed de novo, Hughes neatly refuted his own argument. To permit Congress to "substitute for constitutional courts, in which the judicial power of the United States is vested, an administrative agency . . . for the final determination of the existence of the facts-upon which the enforcement of the constitutional rights of the citizen depend ... would be to sap the judicial power as it exists under the Federal Constitution, and to establish a government of a bureaucratic character alien to our system, wherever fundamental rights depend, as not infrequently they do depend, upon the facts." Juries and masters were distinguishable after all, for the former acted "under the constant superintendance of the trial judge," and the latter's reports were "essentially advisory."

Hughes was right the second time: review of questions of law was inadequate to protect the rights of the parties. It was this insight that had led the framers to authorize Congress to establish lower federal courts. ${ }^{63}$ Moreover, as Alexander Hamilton pointed out, constitutional questions are not the only ones that should be

285 U.S. at 51, 54. This conclusion echoed the position Hughes had taken as governor of New York in 1907 in advocating limited judicial review of public utility commissions. See Pusey, 1 Charles Evans Hughes at 203-04 (cited in note 2). It did seem to suggest that article III required judicial review of questions of law decided by non-article III tribunals.

81285 U.S. at 56-57. The issues held subject to de novo review were whether the injury occurred on navigable waters and whether the relation of master and servant existed: "These conditions are indispensable to the application of the statute, not only because the Congress has so provided explicitly . . . but also because the power of the Congress to enact the legislation turns upon the existence of these conditions." Id. at 55. Related to this conclusion was the reaffirmation in St. Joseph Stock Yards Co. v. United States, 298 U.S. 38 (1936) (Hughes, over critical concurrences by Brandeis, Stone, and Cardozo), that due process required "an independent judicial judgment upon the facts" when administratively prescribed rates were attacked as confiscatory. Id. at 52. See Ohio Valley Water Co. v. Ben Avon Borough, 253 U.S. 287, 289 (1920), discussed in Currie, 1985 Duke L. J. at 1138 n.140 (cited in note 2); Chicago, M. \& St. P. Ry. v. Minnesota, 134 U.S. 418 (1890), discussed in Currie, 52 U. Chi. L. Rev. at 370-75 (cited in note 13). For the subsequent fate of these requirements, see Louis L. Jaffe, Judicial Control of Administrative Action 636-53 (1965).

6285 U.S. at 61 . One may add that juries are explicitly required by the Constitution, and are immune from the presidential and congressional pressures that underlie the tenure and salary provisions.

os Osborn v. Bank of the United States, 22 U.S. 738, 822-23 (1824), noting that without original federal jurisdiction the litigant would have only "the insecure remedy of an appeal upon an insulated point, after it has received the shape which may be given to it by another tribunal." See also Currie, First Hundred Years at 93 n.24, 104 (cited in note 13). 
decided without fear of reprisal. ${ }^{64}$ In suggesting that essentially appellate review of most administrative decisions would satisfy article III, the Court seemed to say that the explicit requirements of tenure and irreducible salary for judges "both of the supreme and inferior courts" applied only to appellate judges. ${ }^{65}$

\section{DARKNESS AT NoON}

By the time 1934 ended, the Court had thus provided strong evidence of a tendency to relax a variety of preexisting limitations on social and economic legislation. For anyone who thought the bad old days were over, however, 1935 was to serve a strong dose of cold water.

84 "[I]t is not with a view to infractions of the Constitution only that the independence of the judges may be an essential safeguard." The Federalist Papers No. 78 at 470 (Heirloom ed. 1966).

Bs Later commentators have recognized that this, rather than the limited requirement of de novo review that originally attracted much attention, was the more significant aspect of the decision. See Jaffe, Judicial Control at 89-90 (cited in note 61); Paul M. Bator et al., Hart and Wechsler's The Federal Courts and the Federal System 338 (2d ed. 1973). Justice Brandeis, joined by Stone and Roberts, would have gone even further, permitting Congress to limit review even of constitutional fact findings, principally because Congress did not have to create lower federal courts at all: "Matters which may be placed within their jurisdiction may instead be committed to the state courts." 285 U.S. at 86-87. State judges, however, are not subject to the congressional and presidential pressures that prompted adoption of the tenure and salary requirements, and allowing them to decide federal cases serves independent goals of federalism that are absent in the case of federal administrative agencies. See Thomas G. Krattenmaker, Article III and Judicial Independence: Why the New Bankruptcy Courts are Unconstitutional, 70 Geo. L. J. 297, 304 (1981); David P. Currie, Bankruptcy Judges and the Independent Judiciary, 16 Creighton L. Rev. 441, 447 (1983).

Two decisions the following year, without citing Crowell, showed there was still life in article III. See O'Donoghue v. United States, 289 U.S. 516, 536 (1933) (Sutherland, over three dissents), which distinguished the cases upholding territorial courts, such as American Ins. Co. v. Canter, 26 U.S. 511 (1828), discussed in Currie, First Hundred Years at 119-22 (cited in note 13), on the ground that the territories were "transitory," in holding that article III protected salaries of District of Columbia judges from reduction; Williams v. United States, 289 U.S. 553, 580-81 (1933) (Sutherland, for a unanimous Court), which artificially concluded that suits brought against the United States with its consent were not article III cases, in order to reconcile reduction of the salaries of Court of Claims judges with the principle that article III powers could be exercised only by article III courts: "since Congress ... may . . . confer upon an executive officer or administrative board, . . or retain for itself, the power to . . . determine controversies respecting claims against the United States, it follows indubitably that such power . . . is no part of the judicial power vested in the constitutional courts." For precedents less favorable to the independence of the judges, see Currie, 1986 Duke L. J. at 131-34 (cited in note 1); for apt criticism of the Williams reading of the jurisdictional clauses of article III, see Bator et al., Hart and Wechsler's Federal Courts at 398-99. 


\section{A. Delegation and Executive Control}

1. Hot oil. The National Industrial Recovery Act was a centerpiece of President Roosevelt's New Deal, a comprehensive shock treatment designed to cure the economy of its depression. Among other things, the act authorized the president to prohibit interstate and foreign transportation of petroleum and its products "produced or withdrawn from storage in excess of the amount permitted . . . by any state law." In Panama Refining Co. v. Ryan, the Court held that the statute unconstitutionally delegated to the president legislative power vested in Congress by article $1 .^{66}$

The principle the Chief Justice invoked was hoary and respectable, but it had never drawn blood before. Recognizing that the president's article II responsibility to execute the laws entailed interstitial policymaking, the Court had upheld a variety of measures against nondelegation arguments. An executive finding that one nation respected our neutrality could reactivate an embargo against another; executive officers could be empowered to set standards of quality and fitness for imports, to protect national forests from deterioration, and to raise tariffs to compensate for high duties or low production costs abroad. ${ }^{67}$ The decisive factor seemed to be that in each case Congress had made the basic policy decision, leaving to the executive only the task of applying a statutory "primary standard" or "intelligible principle." 68

As Cardozo observed in a lone dissent, the provision at stake in Panama left the president no latitude whatever once he decided to act: he was to forbid interstate or foreign commerce in petroleum produced in excess of state limitations. In this respect the law was far more confining than many of those the Court had previously upheld. ${ }^{68}$

What concerned the Court was the absence of any provision

s8 293 U.S. 388 (1935), invalidating the National Industrial Recovery Act of June 16, 1933, Title I, § 9(c), 48 Stat. 195, 200 (1933). See U.S. Const. art. I, § 1: "All legislative powers herein granted shall be vested in a Congress of the United States."

${ }^{67}$ See The Brig Aurora, 11 U.S. 382, 383 (1813); Buttfield v. Stranahan, 192 U.S. 470 (1904); United States v. Grimaud, 220 U.S. 506 (1911); Field v. Clark, 143 U.S. 649 (1892); J. W. Hampton, Jr. \& Co. v. United States, 276 U.S. 394 (1928); Currie, First Hundred Years at 118-19 (cited in note 13); Currie, 52 U. Chi. L. Rev. at 339-43 (cited in note 13); Currie, 1986 Duke L. J. at 138 (cited in note 1).

es See Buttfield, 192 U.S. at 496; J. W. Hampton, Jr. \& Co., 276 U.S. at 409.

(o See 293 U.S. at 434-35. Notwithstanding a lack of persuasive supporting reasons, precedent had essentially disposed of the argument that by allowing state production quotas substantially to determine federal policy the statute invalidly delegated congressional power to the states. See United States v. Hill, 248 U.S. 420 (1919); Currie, 1985 Duke L. J. at 1144 n.167 (cited in note 2). 
limiting the president's discretion whether to act at all: "Section 9(c) does not state whether, or in what circumstances or under what conditions, the President is to prohibit the transportation of the amount of petroleum ... produced in excess of the State's permission. . . . Congress has declared no policy, has established no standard, has laid down no rule."

Earlier opinions had not emphasized that the provisions they upheld were mandatory, but Cardozo could not very well deny that whether to ban commerce in "hot" oil was a fundamental policy question. Instead, he found elsewhere in the legislation implicit criteria to direct and confine the president in answering it. "[B]y reasonable implication the power conferred upon the President by $\S 9(c)$ is to be read as if coupled with the words that he shall exercise the power whenever satisfied that by doing so he will effectuate the policy of the statute as theretofore declared"- that is, when the effect of transporting hot oil "is to promote unfair competition or to waste the natural resources or to demoralize prices or to increase unemployment or to reduce the purchasing power of the workers of the nation."11 In declining to follow this path, the other eight justices seemed to pay little heed to the familiar maxim that statutes should be construed if possible so as to preserve their constitutionality. ${ }^{72}$

70293 U.S. at $415,430$.

${ }^{21}$ Id. at 438,437 . For a view approving this position, see Jaffe, Judicial Control at 63 (cited in note 61). For the view that the majority was right but that the limits it placed on delegation were "formal rather than substantial," see Theodore W. Cousens, The Delegation of Federal Legislative Power to Executive Officials, 33 Mich. L. Rev. 512, 539-40, 544 (1935).

72 See 293 U.S. at 439 (Cardozo, dissenting). For the origins of this venerable principle, see Currie, First Hundred Years at 29-30 (cited in note 13), discussing Mossman v. Higginson, 4 U.S. 12 (1800).

No limiting construction was thought necessary, on the other hand, to sustain the delegation of authority to the president to prohibit the sale of arms to Bolivia or Paraguay if he found such a ban "may contribute to the reestablishment of peace between those two countries." United States v. Curtiss-Wright Corp., 299 U.S. 304, 312 (1936). Assuming that such a delegation would be invalid "if it were confined to internal affairs," Justice Sutherland properly observed that it was easier to uphold statutes authorizing the president to act in foreign matters, since the Constitution itself gave him authority in that field "which does not require as a basis for its exercise an act of Congress." Id. at 315, 319-20. Similar considerations may support the Court's cavalier conclusion in Sibbach v. Wilson \& Co., 312 U.S. 1, 9-10 (1941), that Congress could delegate to the Supreme Court authority to adopt procedural rules with virtually no legislative standards at all. With respect to the authority of courts to adopt their own procedural rules, see also Currie, First Hundred Years at 117-19 (cited in note 13), discussing Wayman v. Southard, 23 U.S. 1 (1825).

For another interestingly broad view of the president's foreign affairs authority, see United States v. Belmont, 301 U.S. 324, 330-31 (1937) (Sutherland), upholding an executive agreement whereby the United States succeeded to claims of Russian citizens expropriated by the Soviet government. As the Court said, the agreement was incidental to United States 
Since the defect the Court had perceived could be mended by a more definitive assertion of congressional will, and since the opinion had been joined by such tolerant justices as Brandeis and Stone, the decision did not necessarily display hostility toward regulation as such, or even toward federal regulation. ${ }^{73}$ Nevertheless it portended rough sailing for other and more important New Deal provisions.

2. Sick chickens. Four months later, in Schechter Corp. $v$. United States, the Court applied the same doctrine to cut the heart out of the statute whose extremities the Panama decision had already amputated. Schechter had been prosecuted for violating a "code of fair competition," promulgated by the President for the poultry business under section 3 of the National Industrial Recovery Act, by failing to comply with the code's minimum wage and maximum hour provisions and by selling "an unfit chicken." 74

The only flaw in the provision nullified in Panama, wrote Chief Justice Hughes, had been the breadth of presidential discretion in determining whether or not to act. In Schechter the difficulty was "more fundamental": there was no "adequate definition of the subject to which the codes [we]re to be addressed." Apart from antimonopoly and hearing provisions and a requirement that trade associations proposing codes to the president be "representative," the president's discretion in this regard was "virtually unfettered." Unlike the "unfair methods of competition" forbidden by the Federal Trade Commission Act, codes of "fair competition" were not limited to anything resembling the established common law. "Rather, the purpose is clearly disclosed to authorize new and controlling prohibitions through codes of laws which would embrace what the formulators would propose, and what the President

recognition of that government and the establishment of diplomatic relations; it could therefore plausibly fit within the president's apparently innocuous authority to "receive Ambassadors," art. II, \& 3, which Sutherland did not mention. See Gerald Gunther, Constitutional Law 368 (11th ed. 1985). More serious was the objection that the treaty clause of article II required Senate consent; in holding that not every "international compact" was a "treaty" without specifying which ones were (compare the distinction in art. I, $\S 10$ between state "treaties" that are absolutely forbidden and "compacts" that Congress may approve), the Court seemed to risk erosion of the Senate's constitutional authority. See Raoul Berger, The Presidential Monopoly of Foreign Relations, 71 Mich. L. Rev. 1, 33-48 (1972); Philip B. Kurland, The Impotence of Reticence, 1968 Duke L. J. 619, 626.

${ }^{73}$ Indeed Congress remedied the defect within six weeks by forbidding interstate transportation of hot oil outright. Connally Hot Oil Act, 49 Stat. 30 (1935). See Robert L. Stern, The Commerce Clause and the National Economy, 1933-1946, 59 Harv. L. Rev. 645, 658 (1946).

74295 U.S. 495, 521-22, 528 (1935).

${ }^{73}$ Id. at $\mathbf{5 3 0 - 3 1 .}$ 
would approve, or prescribe, as wise and beneficient [sic] measures for the government of trades and industries in order to bring about their rehabilitation, correction and development."78

This time the decision was unanimous, and rightly so. As Cardozo noted in a concurring opinion joined by Stone, the power conveyed was "as wide as the field of industrial regulation. ... [A]nything that Congress may do within the limits of the commerce clause for the betterment of business may be done by the President ... by calling it a code. This is delegation running riot." "7 It would no doubt have been impolitic to say so, but it can hardly have escaped the justices that apart from its limitation to business there was little to distinguish what Congress had attempted from the 1933 legislation authorizing Adolf Hitler to govern Germany by decree. ${ }^{78}$ Far from reflecting hostility to federal regulation as such, the delegation decision in Schechter was a salutary reminder of the wisdom of the framers' decision to vest legislative power in a representative assembly. ${ }^{79}$

3. Coal miners. The codes of fair competition in Schechter had been formulated by private trade associations and approved by the President. The requirement of presidential approval made it unnecessary to decide whether a delegation of legislative authority to private persons also would be unconstitutional, ${ }^{80}$ but the opinion left no doubt that it would: "[W]ould it be seriously contended that Congress could delegate its legislative authority to trade or industrial associations or groups so as to empower them to enact the laws they deem to be wise and beneficent for the rehabilitation and expansion of their trade or industries? . . . The answer is obvious. Such a delegation of legislative power is unknown to our

76 Id. at 533-35, 537. For a prediction that the precedents could sustain even this delegation, see Forrest Revere Black, The National Industrial Recovery Act and the Delegation of Legislative Power to the President, 19 Cornell L. Q. 389 (1934).

27295 U.S. at 553.

${ }^{78}$ GBI. 1933, Teil I, S. 141: "Reichsgesetze können ausser in dem in der Reichsverfassung vorgesehenen Verfahren auch durch die Reichsregierung beschlossen werden." ["Imperial statutes may be enacted not only by the procedure provided for in the Constitution of the Empire, but also by the Imperial Executive."] For a glimpse of the delegation issue in modern Germany through American eyes, see David P. Currie, Der Vorbehalt des Gesetzes: Amerikanische Analogien, in Götz, Klein, \& Starck, Die öffentliche Verwaltung zwischen Gesetzgebung und richterlicher Kontrolle 68 (1985).

79 See also David P. Currie, The Distribution of Powers after Bowsher, 1986 S.Ct. Rev. 19, 21-31.

${ }^{80}$ See Schechter, 295 U.S. at 552 (Cardozo, concurring): "The[ir] function is strictly advisory; it is the imprimatur of the President that begets the quality of law. . . . When the task that is set before one is that of cleaning house, it is prudent as well as usual to take counsel of the dwellers." 
law and is utterly inconsistent with the constitutional prerogatives and duties of Congress." 1

The Bituminous Coal Conservation Act of 1935, another New Deal measure, presented the question thus previewed in Schechter. Congress had provided in effect that minimum wages and maximum hours agreed upon by a preponderance of coal miners and producers should bind the entire industry. ${ }^{82}$ Speaking through Justice Sutherland in Carter v. Carter Coal Co. in 1936, the Court lived up to its promise: "The power conferred upon the majority is, in effect, the power to regulate the affairs of an unwilling minority. This is legislative delegation in its most obnoxious form; for it is not even delegation to an official or an official body, presumptively disinterested, but to private persons whose interests may be and often are adverse to the interests of others in the same business." Regulation was "necessarily a governmental function," and a statute attempting to confer regulatory power on private persons was "so clearly arbitrary, and so clearly a denial of rights safeguarded by the due process clause of the Fifth Amendment, that it is unnecessary to do more than refer to decisions of this court which foreclose the question."

Cited for this proposition were not only Schechter, but also two earlier decisions striking down state laws found to have delegated lawmaking authority to private parties. ${ }^{84}$ This was not necessarily to condemn lawmaking by initiative or referendum, whose constitutionality the Court had refused on political question grounds to determine. ${ }^{85}$ The democratic nature of these processes adequately distinguishes them from measures conferring legislative authority on particular interest groups. ${ }^{86}$ But the Court's invoca-

Id. at 537.

${ }^{32}$ See Bituminous Coal Conservation Act of 1935, Pub. L. No. $402, \S 4$ pt. III(g), 49 Stat. 991, 1002.

83298 U.S. 238, 311 (1936).

s4 See Eubank v. Richmond, 226 U.S. 137, 143 (1912); Seattle Trust Co. v. Roberge, 278 U.S. 116, 121-22 (1928). See Currie, 1985 Duke L. J. at 1138 n.140 (cited in note 2). See also Old Dearborn Distributing Co. v. Seagram-Distillers Corp., 299 U.S. 183, 194 (1936) (Sutherland), distinguishing Eubank, Roberge, and Carter in upholding a statute creating a private right of action to recover damages resulting from sales lower than those fixed by "fair trade" (resale price maintenance) agreements to which the defendant need not be a party: "Here, the restriction, already imposed with the knowledge of appellants, ran with the acquisition [of the goods] and conditioned it."

ss Pacific Telephone Co. v. Oregon, 223 U.S. 118 (1912). See also Currie, 1985 Duke L. J. at 1117 n.37 (cited in note 2).

${ }^{8 s}$ See City of Eastlake v. Forest City Enterprises, Inc., 426 U.S. 668, 675 (1976), upholding a requirement that zoning changes be approved by referendum: the nondelegation doctrine "is inapplicable where, as here, rather than . . . a delegation of power, we deal with 
tion of due process rather than article I to support its convincing conclusion did seem to call into question earlier suggestions that the separation of powers at the state level was of no federal concern. For Carter reminds us that due process traditionally meant the executive could act only in accordance with the "law of the land"; the policy behind that prohibition forbids the executive as well as the coal industry to make basic policy. ${ }^{87}$

4. Trade commissioners. William E. Humphrey was a member of the Federal Trade Commission, appointed by President Hoover for a seven-year term and removable by the president "for inefficiency, neglect of duty, or malfeasance in office." In Humphrey's Executor v. United States, the Court held that President Roosevelt had acted unlawfully in removing Humphrey for policy reasons before his term expired. ${ }^{88}$

In Myers v. United States, a few years before, the Taft Court had ringingly held that a statutory requirement of Senate consent to discharge a postmaster impaired the president's article II control over executive functions. ${ }^{89}$ This principle, wrote Justice Sutherland for a unanimous Court in Humphrey's Executor, was inapplicable to the trade commission because it was not an executive agency. "In administering the provisions of the statute in respect of 'unfair methods of competition' - that is to say in filling in and administering the details embodied by that general standard-the commission acts in part quasi-legislatively and in part quasi-judicially. . . . To the extent that it exercises any executive function-as distinguished from executive power in the constitutional sense-it does so in the discharge and effectuation of its quasilegislative or quasi-judicial powers, or as an agency of the legislative or judicial departments of the government."

This was quite remarkable. Previous decisions had upheld delegations of apparently legislative or judicial powers to adminis-

a power reserved by the people to themselves."

${ }^{87}$ See Currie, 52 U. Chi. L. Rev, at 339-40 n.91 (cited in note 13), and cases cited therein; Currie, First Hundred Years at 272 (cited in note 13). Nevertheless, the Court unanimously refused, the year after Carter, to reexamine its conclusion regarding separation of powers at the state level. Highland Farms Dairy, Inc. v. Agnew, 300 U.S. 608, 612 (1937) (Cardozo): "How power shall be distributed by a state among its governmental organs is commonly, if not always, a question for the state itself."

${ }^{88} 295$ U.S. 602 (1935). Strictly speaking, the holding was that Humphrey was entitled to his continuing salary. See Geoffrey P. Miller, Independent Agencies, 1986 S. Ct. Rev. 41, 93-95, arguing for this reason that the decision is not a firm precedent for congressional authority to limit the power of removal.

${ }^{89} 272$ U.S. 52 (1926). See also Currie, 1986 Duke L. J. at 134-38 (cited in note 1).

so Humphrey's Executor, 295 U.S. at 628. 
trative officers on the ground that the executive function itself embraced the elaboration and application of legislative policy. ${ }^{91}$ To deny that the commission's powers were executive was to demonstrate that they could be exercised only by Congress or by the courts.

Even if the Court was right that giving content to the statutory command in deciding cases was not an executive function, the same hardly could be said of the commission's authority to file complaints against offenders. Prosecution is neither legislation nor adjudication but rather a quintessential means of law enforcement.92 If the president cannot control the prosecutor, he cannot fulfill his constitutional duty to "take care that the laws be faithfully executed."9s The message of Humphrey's Executor thus seemed to be that Congress could violate article II if it was willing to violate articles I and III at the same time, as well as the separation of powers. ${ }^{94}$

1 See, e.g., notes 71-73 and accompanying text above (discussing Panama Refining Co. v. Ryan); Murray's Lessee v. Hoboken Land \& Improvement Co., 59 U.S. 272 (1856) (extrajudicial distraint procedure held consistent with article III as an executive function); Ex parte Bakelite Corp., 279 U.S. 438, 451 (1929) (executive officers may adjudicate "matters ... which from their nature do not require judicial determination and yet are susceptible of it"). Humphrey's Executor itself described the Commission as "an administrative body created by Congress to carry into effect legislative policies embodied in the statute." 295 U.S. at 628. See also Bowsher v. Synar, 106 S.Ct. 3181, 3192 (1986): "Interpreting a law enacted by Congress to implement the legislative mandate is the very essence of 'execution' of the law."

'2 See Buckley v. Valeo, 424 U.S. 1, 109-43 (1976), holding that because, among other things, their prosecutorial duties were executive, members of the Federal Election Commission were "Officers of the United States" who consequently could not be appointed by Congress.

es U.S. Const. art. II, § 3. Hughes himself had made a similar argument at the policy level in arguing for gubernatorial removal of bungling members of public service commissions in 1907. See Pusey, 1 Charles Evans Hughes at 202-03 (cited in note 2). Unlike the provision condemned in Myers, and like the one Hughes had advocated in 1907, the provision upheld in Humphrey's Executor permitted the president to discharge a trade commissioner for "inefficiency, neglect of duty, or malfeasance in office." Humphrey's Executor, 295 U.S. at 620 . Since one of the principal goals of the legislation had been to create a commission independent of the president, however, one could not very well twist these restrictive terms to make the failure to follow presidential orders a ground for removal. See 295 U.S. at 624-26, summarizing the legislative history.

" See Currie, $1986 \mathrm{~S}$. Ct. Rev. at 31-36 (cited in note 79). The principle that the same person may not be both prosecutor and judge also is reflected in the concept that due process requires fundamentally fair procedure. See also Tumey v. Ohio, 273 U.S. 510, 523 (1927) (holding that a judge may not be compensated only when he convicts defendants); Lewis Carroll, Alice's Adventures in Wonderland ch. 3 (McKibbin ed. 1899). For a comprehensive contemporaneous assessment of Humphrey's Executor, see Robert E. Cushman, The Constitutional Status of the Independent Regulatory Commissions, 24 Cornell L. Q. 13, 163 (1938). 


\section{B. The Commerce Power}

The nondelegation doctrine only forbade Congress to transfer its authority to others; it cast no doubt on the validity of congressional regulation. Both Schechter and Carter, however, also made clear that Congress itself could not have enacted the challenged measures, and a third decision rendered shortly before Schechter had taken a still more restrictive view.

1. Schechter. The defendants bought live poultry, slaughtered it, and sold it to local retailers. Most of the poultry came from other states. However, as the Court in Schechter said, the interstate journey ended when the birds reached the slaughterhouse: "Neither the slaughtering nor the sales by defendants were transactions in interstate commerce."

The government argued that the wages and hours of slaughterhouse employees and the quality of birds sold affected interstate commerce by influencing the price, quantity, and quality of poultry shipped from one state to another ${ }^{98}$ Chief Justice Hughes, who had written two of the principal decisions on which this argument was based, agreed that Congress had some power to protect interstate commerce from "injury ... . due to the conduct of those engaged in intrastate operations." ulate everything affecting commerce, however, "there would be virtually no limit to the federal power and for all practical purposes we should have a completely centralized government."

95 295 U.S. at 543, citing, among others, Brown v. Houston, 114 U.S. 622 (1885) (upholding state tax on goods after interstate transportation). See Currie, First Hundred Years at $414 \mathrm{n} .78$ (cited in note 13).

295 U.S. at 508-10. See Stern, 59 Harv. L. Rev. at 660 (cited in note 73), concluding that the record respecting any such effects was "meagre" and that "a sounder argument" was the more sweeping one "that depressed business conditions had catastrophically affected all commerce, including interstate, and that a possible remedy was to increase the purchasing power of all wage earners through wage and hour regulation, thereby increasing the demand for products to be shipped in commerce." This argument, Stern conceded, "had . . . little chance of success in the judicial climate of that period." Id. at 661.

${ }_{97} 295$ U.S. at 544, citing, among others, Houston, E. \& W. Tex. Ry. v. United States (Shreveport Rate Case), 234 U.S. 342 (1914) (Hughes) (federal regulation of local rail rates in competition with interstate traffic). See also Baltimore \& Ohio R.R. v. Int. Com. Comm., 221 U.S. 612, 619 (1911) (Hughes) (federal limitation of hours worked in local commerce by employee also engaged in interstate commerce); Currie, 1985 Duke L. J. at 1118-21 (cited in note 2).

ss 295 U.S. at 548. See also Forrest Revere Black, The Commerce Clause and the New Deal, 20 Cornell L. Q. 169, 179 (1935): "Since the depression seriously obstructs the flow of commodities in interstate commerce, it follows that measures reasonably calculated to free business from the burdens of the depression are regulations which will protect and foster interstate commmerce." See generally Thomas Reed Powell, Commerce, Pensions, and Codes, II, 49 Harv. L. Rev. 193 (1935). 
This was true, and it was refreshing to see the Court acknowledge it, for in some of their more recent pronouncements the justices had tended to emphasize the effect on commerce without much attention to whether their decision left anything outside the enumeration of limited federal powers. ${ }^{92}$ Cardozo put the point with his accustomed elegance in an emphatic concurring opinion: "If centripetal forces are to be isolated to the exclusion of the forces that oppose and counteract them, there will be an end to our federal system." 100

As always, it was easier to declare that there were limits than to explain why the particular case lay beyond them. Hughes recurred to the tired distinction between "direct" and "indirect" effects on commerce without satisfactorily distinguishing earlier decisions. $^{101}$ Cardozo abandoned the illusive quest for objective criteria altogether, stressing that " $[t]$ he law [was] not indifferent to considerations of degree" and concluding without elaboration that "[t]o find immediacy or directness here is to find it almost everywhere."102

The candid imprecision of Cardozo's approach reflects the subjective nature of the problem. Surely too, he and all his colleagues were right on the facts of the case: to permit Congress to regulate the wages and hours in a tiny slaughterhouse because of remote effects on interstate commerce would leave nothing for the tenth amendment to reserve.

2. Carter. Five justices thought Schechter governed the commerce clause question in Carter. Coal mining was production, not commerce; Congress could no more regulate what preceded interstate trade than what followed it. Any impact of low wages or long hours in the mining industry on commerce, moreover, was "indirect." It mattered not that the companies involved were large and the effect on commerce great: "The word 'direct' . . . connotes the absence of an efficient intervening agency or condition. ... The distinction between a direct and an indirect effect turns, not upon

"2 See Currie, 1985 Duke L. J. at 1118-21 (cited in note 2), and cases there discussed. 100295 U.S. at 554.

${ }^{102}$ Id. at 546-48. Contrast with the finding of indirectness in Schechter, Baltimore \& Ohio. R.R. v. Int. Com. Comm., 221 U.S. 612 (1911) (hours worked locally by employee also engaged in interstate commerce); Southern Ry. Co. v. United States, 222 U.S. 20, 27 (1911) (couplers on intrastate cars); Shreveport Rate Case, 234 U.S. 342 (1914) (intrastate rail rates). See Currie, 52 U. Chi. L. Rev. at 346-49 (cited in note 13); Currie, 1985 Duke L. J. at 1118-21 (cited in note 2). For criticism of Hughes's distinction, see E. S. Corwin, The Schechter Case-Landmark, or What?, 13 N.Y.U. L.Q. Rev. 151, 162-70 (1936).

102295 U.S. at 554. See also Panhandle Oil Co. v. Knox, 277 U.S. 218, 223 (1928) (Holmes, dissenting): "most of the distinctions of the law are distinctions of degree." 
the magnitude of either the cause or the effect, but entirely upon the manner in which the effect has been brought about."103 Thus Congress itself could not set minimum wages or maximum hours for coal miners.

While the result was the same as in Schechter, the tone of the opinion in Carter was quite different. Conspicuously missing from Carter was Hughes's insistence that Congress had power to prevent harm to commerce regardless of its source. In accents reminiscent of the discredited decision in United States v. E. C. Knight Co., ${ }^{104}$ Sutherland seemed to consider his job essentially done once he had laboriously established the obvious proposition that mining was not itself interstate commerce. ${ }^{105}$

In a separate opinion, Hughes agreed that the labor provisions went "beyond any proper measure of protection of interstate commerce." However, following the analysis he had employed in Schechter, he suggested that additional provisions setting minimum prices for local coal sales might be permissible in order to prevent discrimination against interstate commerce. Cardozo's dissent, joined by Brandeis and Stone, went further: "Within rulings the most orthodox, the prices for intrastate sales of coal have so inescapable a relation to those for interstate sales that a system of regulation for transactions of the one class is necessary to give adequate protection to the system of regulation adopted for the other."106

Both Hughes and Cardozo relied on the Shreveport Rate Case, which had upheld federal regulation of local rail rates. The citation was apt; the provisions in both cases prevented the loss of substantial interstate business to local competition. Finding the price and labor provisions inseparable, the majority nullified the price provisions without considering their merits. ${ }^{107}$ Cardozo, on

${ }^{103}$ Carter, 298 U.S. at 307-08. See the government's ingenious argument that the enumerated powers should be construed in light of Randolph's initial proposal to authorize Congress "to legislate in all cases to which the separate States are incompetent, or in which the harmony of the United States may be interrupted by the exercise of individual Legislation." Id. at 257-58 (oral argument of Mr. Dickenson). This argument, which had been developed in Robert L. Stern, That Commerce which Concerns More States than One, 47 Harv. L. Rev. 1335, 1338-40 (1934), was not easy to reconcile with the Convention's rejection of that proposal in favor of an enumeration. Carter, 298 U.S. at 292.

104156 U.S. 1 (1895). See also Currie, 52 U. Chi. L. Rev. at 346-49 (cited in note 13).

103298 U.S. at $297-310$.

108 Id. at 320 (Hughes), 329 (Cardozo).

102298 U.S. at 312-16. The Court reached this conclusion despite a clause explicitly providing that "[i]f any provision of this Act . . . is held invalid, the remainder of the Act ... shall not be affected thereby." For the obvious objections, see the separate opinions of Hughes and Cardozo, 298 U.S. at 321-24, 334-38; Robert L. Stern, Separability and Separa- 
the other hand, found the challenge to the labor provisions unripe. ${ }^{108}$ The majority thus struck down one provision; the dissenters voted to uphold another.

If precedent was to be respected, the difficult question in Carter was whether the effect of the labor provisions was more like that of the rate regulation upheld in Shreveport or that of similar wage and hour rules struck down in Schechter. In Sutherland's terms, it was arguable that the effect of wages on commerce was always more indirect than that of prices. Low local prices attract customers away from interstate markets; low wages reduce production costs and thus tend to lower prices. ${ }^{109}$ On the other hand, wages paid by huge coal companies clearly have a greater impact on commerce than those paid by a diminutive butcher, and there was no compelling reason for Sutherland's conclusion that the magnitude of the effect had to be ignored. Hughes, the only justice to comment on both the price and the labor provisions, did not say why he found one more acceptable than the other. ${ }^{110}$

Cardozo pointed out once again that it was a mistake to attempt to encompass the governing principle in the single adjective "direct": "Strictly speaking, the intrastate rates [in cases like Shreveport] have a primary effect upon the intrastate traffic and not upon any other, though the repercussions of the competitive system may lead to secondary consequences affecting interstate traffic also. . . . At times, as in [Schechter], the waves of causation will have radiated so far that their undulatory motion, if discernible at all, will be too faint or obscure, too broken by cross-currents, to be heeded by the law. In such circumstances the holding is not directed at prices or wages considered in the abstract, but at prices or wages in particular conditions."111 One regrets that Cardozo did not have the opportunity to show how this unavoidably

bility Clauses in the Supreme Court, 51 Harv. L. Rev. 76 (1937). That Congress had meant what it said was suggested by its prompt reenactment of the price provisions, see Bituminous Coal Act of 1937 , Pub. L. No. 48, § 4 pt. II 50 Stat. 72, which were upheld over McReynolds's dissent in Sunshine Coal Co. v. Adkins, 310 U.S. 381 (1940).

${ }_{108} 298$ U.S. at 324.

109 The effect of wages paid in processing goods that are to be shipped or have been shipped from one state to another, however, may be thought more "direct" than that of wages paid in connection with competing local goods.

${ }^{110}$ Hughes's biographer, who paints the chief justice as a consistent supporter of broad federal authority, says he objected to the labor provisions "chiefly" on delegation grounds. Pusey, Charles Evans Hughes at 746 (cited in note 2). But the opinion flatly added that "[t]he provision goes beyond any proper measure of protection of interstate commerce and attempts a broad regulation of industry within the State." 298 U.S. at 318-19.

11298 U.S. at 327-28. "Perhaps," he added, "if one group of adjectives is to be chosen in preference to another, 'intimate' and 'remote' will be found to be as good as any." 
subjective test applied to minimum wages and maximum hours for coal miners.

3. Alton Railroad. Carter may have been a borderline case after Shreveport, but Sutherland's emphasis on the distinction between production and commerce seemed to cast doubt on Shreveport itself. More startling still was the split decision in Railroad Retirement Board v. Alton R.R. that Congress could not establish a retirement and pension system even for railroad workers indisputably engaged in interstate commerce. ${ }^{112}$

As Hughes argued for four justices in dissent, a long series of decisions had upheld regulations touching interstate railroading. "[N]othing which has a real or substantial relation to the suitable maintenance of [rail] service, or to the discharge of the responsibilities which inhere in it," they argued, "can be regarded as beyond the power of [congressional] regulation."113 Pension plans could reasonably be found to promote transportation by encouraging retirement of superannuated employees, reducing wage costs attributable to seniority, and improving worker morale. ${ }^{114}$

For the majority, Roberts applied an extremely sharp scalpel to these arguments. The fact that railroads were becoming safer as their workers aged showed that pensions had no effect on safety, and in any event the railroads could retire overage workers without pension. Retirement was irrelevant to cost because pay did not increase with seniority, and morale could not be considered without abandoning all limits on federal power. ${ }^{115}$

Not all of this reasoning was logically flawed. ${ }^{116}$ The level of scrutiny it reflected, however, was at opposite poles from the test of necessity and propriety of federal legislation that Marshall had

112295 U.S. 330 (1935), criticized in Thomas Reed Powell, Commerce, Pensions, and Codes, 49 Harv. L. Rev. 1 (1935).

113295 U.S. at 376 (Hughes, joined by Brandeis, Stone, and Cardozo, dissenting). An example of the decisions upholding regulations affecting interstate railroading is Northern Securities Co. v. United States, 193 U.S. 197, 342-54 (1904) (upholding federal antitrust prosecution for creation of holding company eliminating competition between two interstate railroads). See also the railroad cases discussed in Currie, 1985 Duke L. J. at 1118-21 (cited in note 2), and in the Alton R.R. opinions; and see also the irreverent suggestion in Powell, Vagaries and Varieties at 42 (cited in note 52) that after Alton R.R. "[i]t is a regulation of interstate commerce to help railroads but not to help railroad employees."

114295 U.S. at $378-80$.

113 Id. at 362-71. The majority added that workers' compensation was distinguishable because it created an incentive to safety. Id. at 370 .

118 The last argument was refuted by the fact that the measure was confined to an interstate industry, and the increase in safety attributable to technological advances did not disprove the self-evident risks created by elderly workers. 
laid down in the national bank case. ${ }^{117}$ The tenor of the opinion was inconsistent not only with the judicial restraint exercised with Roberts's concurrence in reviewing insurance regulation in O'Gorman, but also with Roberts's own sympathetic search for debatable bases on which to uphold the chain store tax in Jackson.118

Schechter was an obvious case, and Carter may have been right even after Shreveport. But one would have to go back to the 1908 decision forbidding Congress to protect the union rights of interstate rail workers ${ }^{110}$ to find another decision in which the commerce clause was so grudgingly construed as in Alton Railroad. ${ }^{\mathbf{1 2 0}}$

\section{Taxing and Spending}

1. Taxation as regulation. In the Child Labor Tax Case in 1922, the Court had invalidated a federal tax as a pretext for regulating a subject Congress could not regulate directly. ${ }^{121}$ In 1935 and 1936 the Court invalidated two more.

One of these was in Carter. The Bituminous Coal Conservation Act imposed a 15 percent gross receipts tax but largely exempted producers who adhered to the wage and price standards. "It is very clear," wrote Sutherland, "that the 'excise tax' is not imposed for revenue but exacted as a penalty to compel compliance with the regulatory provisions of the act."122 No justice took issue with this conclusion, and the prohibitive nature of the exaction supports it. Sutherland did not try to distinguish McCray $v$. United States, which had upheld an equally prohibitive federal tax

${ }^{137}$ See Currie, First Hundred Years at 160-65 (cited in note 13), discussing McCulloch v. Maryland, 17 U.S. 316 (1819).

118 Though different constitutional provisions were involved in these cases, Roberts acknowledged in Alton R.R. that, as Justice Harlan had established many years before, see Mugler v. Kansas, 123 U.S. 623, 661 (1887), discussed in Currie, First Hundred Years at 375-77 (cited in note 13), the due process and necessary and proper clauses both required that legislation be an appropriate means to a legitimate end. 295 U.S. at 347-48 n.5.

110 Adair v. United States, 208 U.S. 161, 178 (1908), discussed in Currie, 52 U. Chi. L. Rev. at 352-53 (cited in note 13).

${ }_{120}$ See Osmond K. Fraenkel, Constitutional Issues in the Supreme Court, 1934 Term, 84 U. Pa. L. Rev. 345, 351 (1936), arguing that Alton R.R. "will probably rank with Lochner v. New York and Adkins v. Children's Hospital as high-water marks of reaction."

121259 U.S. 20 (1922) (invalidating 10 percent excise tax on employers of child labor), discussed in Currie, 1986 Duke L. J. at 110-12 (cited in note 1). See also Hill v. Wallace, 259 U.S. 44 (1922) (invalidating tax on grain futures as impermissible effort at regulation).

123 See 298 U.S. at $280-81,289$. See also id. at 289 ("The whole purpose of the exaction is to coerce what is called an agreement-which, of course, it is not, for it lacks the essential element of consent. One who does a thing in order to avoid a monetary penalty does not agree; he yields to compulsion precisely the same as though he did so to avoid a term in jail."). 
on yellow margarine. ${ }^{123}$

The year before, in United States $v$. Constantine, the Court had struck down a federal excise tax on persons selling liquor in violation of state law. That the tax singled out criminals and that the amount was forty times that levied on lawful dealers, wrote Justice Roberts, showed that "the purpose [was] to impose a penalty as a deterrent and punishment of unlawful conduct." Cardozo, joined by Brandeis and Stone, argued in dissent that the higher profits and enforcement costs associated with illegal activities afforded plausible reasons of revenue policy for the discrimination and protested that the Court's search for Congress's true motive had extended "the process of psychoanalysis . . . to unaccustomed fields."124

Even the Child Labor Tax Case had confirmed, as Cardozo argued, that an "incidental motive" to influence conduct immune from federal regulation did not condemn otherwise permissible taxes as pretextual; incentives are unavoidable in any tax system. ${ }^{225}$ In the past the Court had been unduly reluctant to look behind federal taxes even when they appeared to serve no legitimate federal purpose. ${ }^{126}$ Since nothing of the sort could be said of a $\$ 1,000$ tax on an illegal liquor business, Constantine seemed to go too far in the opposite direction. ${ }^{127}$

2. Federal grants. In Carter and Constantine, Congress had attempted to use taxation as a stick to discourage undesirable conduct it could not forbid. In United States $v$. Butler, it attempted to use federal grants as carrots to encourage desirable conduct it could not require. ${ }^{128}$

In an effort to reduce surpluses that diminished farm income, the Agricultural Adjustment Act authorized the secretary of agriculture to subsidize farmers who agreed to limit their production. Only Stone, Brandeis, and Cardozo voted to sustain the statute, 13).

${ }^{123} 195$ U.S. 27 (1904), discussed in Currie, 52 U. Chi. L. Rev. at 356-57 (cited in note

134296 U.S. 287, 295, 297-99 (1935).

${ }^{225}$ See Child Labor Tax Case, 259 U.S. at 38; Constantine, 296 U.S. at 297-98 (Cardozo, dissenting); Robert E. Cushman, Social and Economic Control Through Federal Taxation, 18 Minn. L. Rev. 759, 764 (1934).

${ }^{128}$ See McCray, 195 U.S. 27 (prohibitive tax on colored margarine); United States v. Doremus, 249 U.S. 86 (1919) ( $\$ 1$ annual tax on persons engaged in the production or distribution of narcotics), discussed in Currie, 1985 Duke L. J. at 1124-25 (cited in note 2).

${ }_{127}$ See Osmond K. Fraenkel, Constitutional Issues in the Supreme Court, 1935 Term, 85 U. Pa. L. Rev. 27, 29 (1936): Constantine "marked a departure from earlier cases which had refused to test taxes by their motives."

128 297 U.S. 1 (1936). 
and Roberts wrote for the majority. ${ }^{129}$

Roberts has been widely pilloried for commencing his discussion with the statement that the Court's task was simply "to lay the article of the Constitution which is invoked beside the statute which is challenged and to decide whether the latter squares with the former."130 This unfelicitous choice of words suggested a mechanical conception of judicial review inconsistent with the open-endedness of the text. Yet Roberts did not deny that the task required the exercise of judicial judgment. The point he was trying to make was a worthy and important one: "This court neither approves nor condemns any legislative policy. Its delicate and difficult office is to ascertain and declare whether the legislation is in accordance with, or in contravention of, the provisions of the Constitution."131

The only constitutional provision invoked to support the statute was the opening clause of article I, section 8, which authorizes Congress " $[t]$ o lay and collect Taxes, Duties, Imposts and Excises, to pay the Debts and provide for the common Defence and general Welfare of the United States."132 The text can be read to confer one power or four: "to pay the debts . . ." might mean "and to pay the debts . . ." or "in order" to do so. The structure and history of the Constitution, however, had persuaded even so zealous a nationalist as Story that the clause did not give Congress an independent power to "provide for the . . . general Welfare." The Court unanimously agreed: such a construction would make "the government of the United States . . ., in reality, a government of general and unlimited powers, notwithstanding the subsequent enumeration of

120 The suit was brought by receivers of a corporation that had been assessed a special processing tax to pay for the grants. Taxpayer standing to challenge expenditures in general had been denied in Frothingham v. Mellon, 262 U.S. 447 (1923), because the impact of spending upon the taxpayer was so tenuous. See Currie, 1986 Duke L. J. at 122-24 (cited in note 1). Butler presented no such difficulty. Since the processing tax was earmarked for the subsidies under attack, if there were no spending there would be no tax either. See 297 U.S. at $57-61$.

${ }^{130} 297$ U.S. at 62. See, e.g., Alexander M. Bickel, The Least Dangerous Branch 90 (2d ed. 1986); Vincent M. Barnett, Jr.; Constitutional Interpretation and Judicial Self-Restraint, 39 Mich. L. Rev. 213, 217 (1940); Arthur M. Schlesinger, The Politics of Upheaval 458 (1960) ("slot-machine theory of jurisprudence"); Powell, Vagaries and Varieties at 42-43 (cited in note 52) ("Try as I will, I cannot bring myself to admire both the candor and the capacity of the men who write such things to be forever embalmed in the official law reports.").

${ }^{231} 297$ U.S. at 63 . See id. at 63 ("The only power . . . [the Court] has, if such it may be called, is the power of judgment.").

138 The United States did not contend that the act was a valid exercise of the commerce power. Id. at 64 . 
specific powers.' . . [T] [The only thing granted is the power to tax for the purpose of providing funds for payment of the nation's debts and making provision for the general welfare.". 133

This authority to tax and spend for the general welfare, however, was not, as Madison had asserted, "confined to the enumerated legislative fields committed to Congress."134 Such an interpretation, Roberts argued, would make the general welfare provision "mere tautology, for taxation and appropriation are or may be necessary incidents of the exercise of any of the enumerated legislative powers." Thus, as Hamilton and Story had argued, "Congress . . . has a substantive power to tax and to appropriate, limited only by the requirement that it shall be exercised to provide for the general welfare of the United States" and not "by the direct grants of legislative power found in the Constitution."136

It seemed to follow from this conclusion, as Justice Stone argued in dissent, that in a nationwide agricultural depression "the expenditure of public money in aid of farmers" was one for "the general welfare" of the United States. ${ }^{136}$ Significantly, Roberts did

1s3 Id. at 64 , quoting Joseph Story, 1 Commentaries on the Constitution of the United States $\S 907$ (1833). For the same position, see Edward S. Corwin, The Spending Power of Congress-Apropos the Maternity Act, 36 Harv. L. Rev. 548, 551 (1923), reprinted in Richard Loss, ed., 1 Corwin on the Constitution 246, 248 (1981).

1s4 See Butler, 297 U.S. at 64.

193 Id. at 65, 65-66. See Alexander Hamilton, 1791 Report on the Subject of Manufactures (1791), reprinted in Harold C. Syrett, ed., 10 Papers of Alexander Hamilton 230, 30204 (1966); Story, 1 Commentaries at ch. 14 (cited in note 133); Corwin, 36 Harv. L. Rev. at 550-80, reprinted in Loss, ed., 1 Corwin on the Constitution at 249-69 (cited in note 133). Hughes later wrote that he considered this broad interpretation "the most 'significant and important ruling in the Butler case." "See Pusey, 2 Charles Evans Hughes at 743 (cited in note 2). In agreement is John W. Holmes, The Federal Spending Power and State Rights, 34 Mich. L. Rev. 637, 637 (1936) which argues that Butler "point[ed] the way toward unprecedented expansion of federal functions."

158 297 U.S. at 79. The refusal of an early Congress to provide disaster relief for a single community after debate had raised serious constitutional doubts tends to support Hamilton's insistence that "the object to which an appropriation of money is . . . made [must] be General and not local; its operation extending in fact, or by possibility, throughout the Union, and not being confined to a particular spot." Syrett, ed., 10 Papers of Hamilton at 303 (cited in note 135) (emphasis in original). See also 6 Annals of Congress 1712-27 (1796). Story, who agreed with Hamilton's conclusion, added that expenditures for foreign palaces or for "propagating Mahometanism among the Turks . . . would be wholly indefensible upon constitutional principles." Story, 1 Commentaries at $\$ 922$ (cited in note 133). In fact, even foreign and local conditions may affect the general welfare; modern foreign aid, for example, is not entirely eleemosynary. In any event, the problem to which the farm subsidies were directed was neither foreign nor local. One might have argued that aid for a particular segment of the population, even if nationally distributed, did not serve the "general" welfare. Compare Loan Association v. Topeka, 87 U.S. 655 (1875) (striking down municipal aid to private manufacturer for want of public purpose), discussed in Currie, First Hundred Years at 381-82 (cited in note 13). But most expenditures benefit some persons more than 
not deny that it was: "We are not now required to ascertain the scope of the phrase 'general welfare of the United States' or to determine whether an appropriation in aid of agriculture falls within it." Even if it did, "another principle embedded in our Constitution prohibits the enforcement of the Agricultural Adjustment Act. The act invades the reserved rights of the states" because its provisions "are . . . means to [the] unconstitutional end" of "regulat[ing] and control[ling] agricultural production, a matter beyond the powers delegated to the federal government."137

With such respect as may be due, as the noncommittal phrase goes, this is nonsense. Having assumed that promoting agriculture was a legitimate end of federal spending, Roberts was in a poor position to argue that it was an unconstitutional one. Having held that the spending power was not limited by the enumeration of other congressional powers, he was hopelessly inconsistent in doing so on the ground that Congress had no independent authority to regulate agriculture. ${ }^{138}$ The Court's reliance on Marshall's warning against the pretextual use of federal powers and on such derivative precedents as the Child Labor Tax Case was therefore misplaced, for under Roberts's own test the law was not a pretext for the accomplishment of an illegitimate purpose. ${ }^{139}$

Roberts went on to insist that the law was regulatory in effect because it was coercive: "The farmer, of course, may refuse to comply, but the price of such refusal is the loss of benefits. The amount offered is intended to be sufficient to exert pressure on him to agree to the proposed regulation."140 Stone's response in dissent was crushing: "The power of Congress to spend is inseparable from persuasion to action over which Congress has no legisla-

others, and it would have been hard to deny that the plight of the farmers posed serious problems for the nation as a whole.

137297 U.S. at 68.

138 See Powell, Vagaries and Varieties at 82-83 (cited in note 52), adding that "Mr. Justice Roberts drew from a major premise what he had expressly excluded from it."

130 See 297 U.S. at 68-70. For the same reason, the Court's invocation of cases applying the doctrine of unconstitutional conditions, see id. at 71-72, citing Frost Trucking Co. v. Railroad Com., 271 U.S. 583 (1926), also was misplaced. Indeed, Roberts's broad reading of the tax power in Butler arguably cast doubt on the Child Labor Tax Case itself: if the tax power could be employed for any purpose serving the general welfare, then taxation for the purpose of preventing child labor was for a legitimate purpose. Butler need not be read this broadly, however, for Roberts preserved the requirement of a revenue purpose by defining the taxing power as the power to tax "for the purpose of providing funds" with which to promote the general welfare. 297 U.S. at 64. See Currie, 1985 Duke L. J. at 1122 (cited in note 2), discussing Hammer v. Dagenhart, 247 U.S. 251 (1918); text accompanying notes 185-86, discussing United States v. Darby, 312 U.S. 100 (1941).

140297 U.S. at $70-71$. 
tive control. Congress may not command that the science of agriculture be taught in state universities. But if it would aid the teaching of that science by grants to state institutions, it is appropriate, if not necessary, that the grant be on the condition ... that it be used for the intended purpose."141 Roberts protested that "[t]here is an obvious difference between a statute stating the conditions upon which moneys shall be expended and one effective only upon assumption of a contractual obligation to submit to a regulation which otherwise could not be enforced."142 The difference was indeed obvious, but so was its irrelevance: in either case Congress has purchased compliance with provisions it could not have imposed directly. ${ }^{143}$

All this floundering was motivated by the same concern that had underlain efforts to limit the commerce power in cases from E.C. Knight to Carter. If Congress could buy reductions in acreage, said Roberts, it could buy anything else it liked. It could not be that the framers of the Constitution, who "in erecting the federal government, intended sedulously to limit and define its powers, ... nevertheless by a single clause gave power to the Congress to tear down the barriers, to invade the states' jurisdiction, and to become a parliament of the whole people."144

The concern was justified, but it was a little late to assert it. Roberts gave the game away when he accepted Hamilton's argument that Congress could spend for any purpose that served the general welfare. As Stone pointed out, the power to spend is the power to make offers that cannot be refused. Such authority is incompatible with the basic premise of limited federal power.

Roberts's objection to Madison's alternative interpretation of the clause was not convincing. McCulloch $v$. Maryland teaches both that redundancy is not foreign to the Constitution (the necessary and proper clause and the tenth amendment having been added out of an abundance of caution) and that the power to tax

111 Indeed, he argued, "[e]xpenditures would fail of their purpose and thus lose their constitutional sanction if their terms of payment were not such that by their influence... the permitted end would be attained." Id. at 83 .

142 Id. at 73.

14s See id. at 83-84 (Stone, dissenting) ("It makes no difference that there is a promise to do an act which the condition is calculated to induce. Condition and promise are alike valid since both are in furtherance of the national purpose for which the money is appropriated."). Roberts would have been better advised to focus upon content rather than form. Conditions or promises relating to the use of the granted funds themselves arguably might have been distinguished from those unrelated to the use of the money, since if the latter are permitted, there is indeed no practical limit to federal power.

144 Id. at 78. 
for purposes elsewhere enumerated would not be redundant (since it "cannot be implied as incidental to other powers"). ${ }^{145}$ It would indeed have been astounding for the framers to leave to the vagaries of implication their most important departure from the Articles of Confederation. ${ }^{\mathbf{1 4 6}}$

A glimpse at those Articles, in fact, affords an invaluable clue as to the purpose of the general welfare clause, for the words are taken directly from that document: "All charges of war, and all other expences that shall be incurred for the common defence or general welfare, and allowed by the united states in congress assembled, shall be defrayed out of a common treasury, which shall be supplied by the several states in proportion to the value of all land within each state."147 This provision granted no authority to spend at all; it merely prescribed how Congress was to defray such expenses as might be incurred pursuant to authority elsewhere given.

The only significant change made in this provision in 1789 was the addition of a power to tax. Far from being redundant, the general welfare clause provided that legitimate expenses should be paid out of federal taxes instead of state contributions. There is no evidence that it was meant to expand the purposes for which expenditures might be made.

Justice Roberts therefore may well have reached the right result in striking down the Agricultural Adjustment Act, ${ }^{148}$ but by

14317 U.S. 316, 406, 409, 411, 420-21 (1819), discussed in Currie, First Hundred Years at 160-65 (cited in note 13).

146 See Federalist No. 30 at 189 (Alexander Hamilton) (arguing that the inadequacy of the revenue provisions of the Articles reduced the Confederation to a condition "which affords ample cause, both of mortification to ourselves, and of triumph to our enemies").

147 Articles of Confederation art. VIII (1781).

148 In Loss, ed., Corwin on the Constitution at 253-69 (cited in note 133), Professor Corwin collected impressive instances of broad construction of the general welfare clause by figures as diverse as Washington and Calhoun, and pointed to numerous federal statutes spending for such purposes as lighthouses, internal improvements, and the promotion of agriculture or education. As Corwin conceded, id. at 267, internal improvements had been upheld as necessary and proper to the commerce, postal, and war powers. See Currie, First Hundred Years at 275 n.298, 429-30 (cited in note 13). However, these powers were not the basis of the original argument for their validity, and they fail to explain the grants for agriculture or education. Since this broad interpretation had been controversial, it does not disprove the conclusion as to original intent suggested by the Articles of Confederation; but by 1936 it may have been a little late to deny it respect as what Justice Frankfurter was later to term a "gloss" on the Constitution. See Youngstown Sheet \& Tube Co. v. Sawyer, 343 U.S. 579, 610 (1952) (concurring opinion): "Deeply embedded traditional ways of conducting government cannot supplant the Constitution ...., but they give meaning to the words of a text or supply them." See also J. A. C. Grant, Commerce, Production and the Fiscal Powers of Congress: II, 45 Yale L. J. 991, 1000 (1936) (Hamiltonian view too embed- 
conceding too much he made it seem quite untenable; and that boded poorly for the future of the federal system. ${ }^{148}$

\section{Other Limitations}

It was not only article I that the Court began to read narrowly in 1935. Other decisions of the same time suggested a return to more restrictive understanding of other limits on both federal and state authority.

1. Minimum wages. The most notable of these was Morehead $v$. New York ex rel. Tipaldo, a five-to-four due process decision striking down yet another minimum wage law on the authority of Adkins $v$. Children's Hospital. ${ }^{\mathbf{1 5 0}}$ After Nebbia, the Court might have been expected to come out the other way. By abandoning the requirement that the business be "affected with a public interest," that decision had seemed to mean that what the Court had once dismissed as impermissible "leveling"- the effort to ameliorate the effects of unequal bargaining power-had become a legitimate legislative goal, even if the justices were not yet prepared to recognize the palpable relation between low wages and both crime and ill health. ${ }^{151}$

Most significantly, as Hughes pointed out in dissent, the law

ded by the "forces of history" to undo).

${ }^{249}$ In striking contrast to the decisions of this period narrowly interpreting domestic federal powers was Justice Sutherland's sweeping conclusion in United States v. CurtissWright Corp., 299 U.S. 304, 315-16 (1936), over a dissent by Justice McReynolds, that the United States possessed plenary authority over foreign affairs without regard to the limited enumeration in article I: "The broad statement that the federal government can exercise no powers except those specifically enumerated in the Constitution, and such implied powers as are necessary and proper to carry into effect the enumerated powers, is categorically true only in respect of our internal affairs." The conclusion that the framers intended to convey plenary authority over foreign affairs is hard to avoid in light of history; but Sutherland's peculiar argument that "the states severally never possessed international powers," id. at 316, has been severely criticized. See Julius Goebel, Jr., Constitutional History and Constitutional Law, 38 Colum. L. Rev. 555, 572 (1938); Charles A. Lofgren, United States v. Curtiss-Wright Export Corporation: An Historical Reassessment, 83 Yale L. J. 1 (1973); David M. Levitan, The Foreign Relations Power: An Analysis of Mr. Justice Sutherland's Theory, 55 Yale L. J. 467 (1946); C. Perry Patterson, In re the United States v. The Curtiss-Wright Corporation, 22 Tex. L. Rev. 286 (1944); Louis Henkin, Foreign Affairs and the Constitution 23-25 (1972). Since the case involved a regulation of foreign commerce clearly within article I, section 8, Sutherland's remarks went far beyond the necessities of the case.

sso Morehead v. New York ex rel. Tipaldo, 298 U.S. 587 (1936); Adkins v. Children's Hospital, 261 U.S. 525 (1923).

${ }^{151}$ See the discussion of Nebbia in notes 28-33 and accompanying text; of Adkins in Currie, 1986 Duke L. J. at 76-77 (cited in note 1); and of "leveling" in Currie, 52 U. Chi. L. Rev. at 378-82 (cited in note 13), and Currie, 1985 Duke L. J. at 1129-31 (cited in note 2). The modern economic literature arguing that minimum wage laws reduce employment is summarized in Posner, Economic Analysis at 28 (cited in note 27). 
in Morehead had been drafted to meet the objection most stressed in Adkins. "The feature of this statute which, perhaps more than any other, puts upon it the stamp of invalidity," Justice Sutherland had complained in that case, "is that it exacts from the employer an arbitrary payment for a purpose and upon a basis having no causal connection with his business. ... The moral requirement implicit in every contract of employment, viz, that the amount to be paid and the service to be rendered shall bear to each other some relation of just equivalence, is completely ignored."152

By contrast, the New York law in Morehead forbade only those wages that were "both less than the fair and reasonable value of the services rendered and less than sufficient to meet the minimum cost of living necessary for health."16s The Court had struck down the law in Adkins because it required employers to solve a problem they had not caused; the law they struck down in Morehead cured that defect by imposing on the employer only the reasonable cost of his business.

Brushing aside the crucial language Hughes quoted from $A d-$ kins, Justice Butler for the majority insisted that that decision had invalidated all minimum wage laws. ${ }^{154}$ More surprisingly still, he refused even to consider whether Adkins was still law, on the ground that the question had not been raised in the petition for review. Justice Stone in a second dissent pointed tellingly to the petition's statement that "the circumstances prevailing under which the New York law was enacted call for a reconsideration of the Adkins case in the light of the New York act." "More sweepingly, he attacked the Court's premise: "I know of no rule or practice by which the arguments advanced in support of an application for certiorari restrict our choice between conflicting precedents in deciding a question of constitutional law which the petition, if granted, requires us to answer."1ss

The majority's ringing restatement of Adkins did little to encourage the hope that that decision would be overruled even if the question were more explicitly presented; and as in Alton Railroad it was Justice Roberts who cast the decisive vote against

${ }^{132}$ Adkins, 261 U.S. at 558, quoted in Morehead, 298 U.S. at 623-24 (Hughes, dissenting, joined by Brandeis, Cardozo, and Stone).

16s 298 U.S. at $605,621$.

136 Id. at 610-14. Butler did not explain whether the fault lay in the illegitimacy of the legislature's goals or in the inappropriateness of the means for attaining them.

${ }^{165}$ Id. at 636. 
regulation. ${ }^{156}$

2. Other cases. Morehead did not stand alone as evidence of the vitality of extraneous limitations on state and federal legislation. Alton Railroad invoked the due process clause of the fifth amendment as a second ground for striking down various provisions of the railroad retirement law. ${ }^{157}$ Several decisions cited either due process or full faith and credit in imposing territorialist limitations on state taxation and choice of law. ${ }^{158}$ Louisville Bank v. Radford unanimously invalidated a federal measure for the relief of insolvent farmers as an uncompensated taking of property from

186 The minimum wage law in Morehead applied only to women and children, and there was a foretaste of modern equal protection analysis in Justice Butler's observation that "prescribing of minimum wages for women alone would unreasonably restrain them in competition with men and tend arbitrarily to deprive them of employment and a fair chance to find work." Id. at 617. The dissenters protested, in terms then viewed as progressive, that states were entitled to conclude that women needed special protection. See id. at 629-30 (Hughes, dissenting).

167295 U.S. at 348-62 (objecting principally to provisions found to operate retroactively or to treat all railroads "as a single employer" and holding them inseparable). The same four justices who dissented from the commerce clause holding largely dissented from these conclusions as well, although they agreed with the majority that for Congress to require the extension of pensions to those no longer employed by the railroads was arbitrary and beyond its power. Id. at 384-92, 389 (Hughes, dissenting).

${ }^{168}$ See Baldwin v. Missouri, 281 U.S. 586 (1930) (McReynolds, over dissents by Holmes, Brandeis, and Stone) (only owner's domicile may tax bank accounts, bonds, and notes); Senior v. Braden, 295 U.S. 422 (1935) (McReynolds, over dissents by Stone, Brandeis, and Cardozo) (state may not tax intangible interest in foreign land); Home Ins. Co. v. Dick, 281 U.S. 397 (1930) (Brandeis) (state may not invalidate clause in foreign contract limiting time for suit); Bradford Elec. Co. v. Clapper, 286 U.S. 145 (1932) (Brandeis) (state of injury must respect exclusivity provision in workers' compensation law of employment state); Hartford Co. v. Delta Co., 292 U.S. 143 (1934) (Roberts) (same as Dick, despite more substantial contacts with forum state); Broderick v. Rosner, 294 U.S. 629 (1935) (Brandeis) (shareholder's state must enforce shareholder liability law of state of incorporation); John Hancock Ins. Co. v. Yates, 299 U.S. 178 (1936) (Brandeis) (law of place of contracting determines effect of fraud in insurance application). See also Young v. Masci, 289 U.S. 253, 258 (1933) (Brandeis) (allowing New York to make New Jersey automobile owner liable for negligence of bailee in New York) ("Liability for a tort depends upon the law of the place of the injury."). For criticism of this line of cases, see Charles L. B. Lowndes, Spurious Conceptions of the Constitutional Law of Taxation, 47 Harv. L. Rev. 628 (1934); Joseph H. Beale, Two Cases on Jurisdiction, 48 Harv. L. Rev. 620 (1935).

The Court also appropriately furthered the purposes of the full faith and credit clause by requiring one state to respect another's judgments for child support, Yarborough v. Yarborough, 290 U.S. 202 (1933) (Brandeis, over an emotional dissent by Stone), and for taxes, Milwaukee County v. White Co., 296 U.S. 268 (1935) (Stone) (effectively previewed in Robert A. Leflar, Extrastate Enforcement of Penal and Governmental Claims, 46 Harv. L. Rev. 193 (1932)). For earlier decisions in these fields, see Currie, 52 U. Chi. L. Rev. at 375-78 (cited in note 13); David P. Currie, The Constitution in the Supreme Court: Full Faith and the Bill of Rights, 1889-1910, 52 U. Chi. L. Rev. 867, 880-97 (1985); Currie, 1985 Duke L. J. at 1138-39 n.140 (cited in note 2). 
creditors. ${ }^{159}$ Two unanimous decisions striking down state legislation even showed that, despite Blaisdell, there was still some life in the contract clause. ${ }^{160}$ Perry $v$. United States invented a spanking new limitation in concluding that the grant of power to borrow implicitly forbade the United States to welsh on its obligations: money can be borrowed only if it will be paid back. ${ }^{101}$

The invalidation of a graduated state sales tax in Stewart Dry Goods Co. v. Lewis showed that equal protection too was alive and well in economic cases despite the chain store cases. ${ }^{162}$ Even the forgotten privileges or immunities clause of the fourteenth amendment was disinterred to strike down a preference for local investment in Colgate v. Harvey. ${ }^{163}$ Baldwin v. G.A.F. Seelig demon-

185 295 U.S. 555 (1935) (Brandeis) (invalidating Frazier-Lemke Act). See also Nashville, C. \& St. L. Ry. v. Walters, 294 U.S. 405 (1935) (Brandeis, over Stone and Cardozo, dissenting), which held that a railroad could not be required to pay for a grade separation promoting only convenience and not safety. These holdings followed easily from Brandeis's sensible distinction between forbidding a person to injure others and requiring him to help them. See Currie, 1986 Duke L. J. at 92-99 (cited in note 1), discussing Pennsylvania Coal Co. v. Mahon, 260 U.S. 393 (1922).

${ }^{100}$ W.B. Worthen Co. v. Thomas, 292 U.S. 426 (1934) (Hughes) (exemption of insurance benefits from garnishment to satisfy preexisting debts); Worthen Co. v. Kavanaugh, 295 U.S. 56 (1935) (Cardozo) (severe impairment of security for preexisting debts).

161294 U.S. 330 (1935) (Hughes, with Stone declining to reach the issue). The case involved a congressional effort to pay off in depreciated currency obligations expressly stated in terms of gold. See also id. at 354 (invoking $\S 4$ of the fourteenth amendment, which provides that " $[t]$ he validity of the public debt of the United States . . . shall not be questioned"); Phanor J. Eder, A Forgotten Section of the Fourteenth Amendment, 19 Cornell L. Q. 1 (1933). The taking clause would have furnished a more traditional basis for the decision; in reducing the value of the obligations, the government had enriched itself without compensating its victim. In a companion case essentially governed by the Legal Tender cases (discussed in Currie, First Hundred Years at 321-29 (cited in note 13) and in John Dickinson, The Gold Decisions, 83 U. Pa. L. Rev. 715 (1935)), the Court held due process was not offended by a similar effort directed toward private contracts. Norman v. B. \& 0 . RR. Co., 294 U.S. 240 (1935) (Hughes, over the expected four dissents). See also John P. Dawson, The Gold Clause Decisions, 33 Mich. L. Rev. 647 (1935), and Charles S. Collier, Gold Contracts and Currency Regulation, 23 Cornell L. Q. 520 (1938) (both tracing the government's efforts to article I, § 8's provision empowering Congress to "regulate the value" of money). Moreover, even in Perry the Government ultimately got its way because of the Chief Justice's bizarre conclusion (over the same four dissents) that the bondholders had lost nothing by the enormous depreciation of their rights. See 294 U.S. at 354-58; Henry M. Hart, Jr., The Gold Clause in United States Bonds, 48 Harv. L. Rev. 1057, 1077-81 (1935); Powell, Vagaries and Varieties at 86 (cited in note 52) (" $[\mathrm{H}]$ ow it could be held that Congress may not renege on a national promise to pay in gold of specified density, and then apply to the bondholder the tort measure of damages instead of the contract one, well nigh passes comprehension."). Roosevelt had gone so far as to prepare a speech justifying disobedience of judicial orders for delivery in case of an adverse decision. See Pusey, 2 Charles Evans Hughes at 736 (cited in note 2).

162294 U.S. 550 (1935) (Roberts, over three dissents).

16s 296 U.S. 404, 430 (1935) (Sutherland, over dissents of Stone, Brandeis, and Cardozo), building upon the unpedigreed right to travel recognized in Crandall v. Nevada, 73 
strated the strength of the negative effect of the commerce clause by rubbing out a state law designed to place local and out-of-state milk sellers on an equal footing. ${ }^{164}$ The Court seemed rather strict in holding that both railroading and water distribution were "governmental" functions immune from taxation by other governments. ${ }^{188}$ Finally, in forbidding Congress to allow local governments to discharge their debts in federal court, it perversely employed the immunity doctrine to the detriment of its intended beneficiaries. ${ }^{168}$

U.S. 35 (1868), to conclude that " $[t]$ he right . . . to make a lawful loan of money in any state other than that in which the citizen resides is a privilege equally attributable to his national citizenship". According to Justice Stone, the Court decided to rely on the privileges or immunities clause only after it became clear that an equal protection challenge was untenable. See Mason, Harlan Fiske Stone at 399-402 (cited in note 12). For contemporaneous criticism, see Pendleton Howard, The Privileges and Immunites of Federal Citizenship and Colgate v. Harvey, 87 U. Pa. L. Rev. 262 (1939); Fraenkel, 85 U. Pa. L. Rev. at 40 (cited in note 127) (arguing that Colgate "illustrates the capacity of the Court to find in the Constitution language appropriate to every need, at least when property rights are involved"). For the earlier fate of this clause, see Currie, First Hundred Years at 342-51, 363-64 (cited in note 13).

${ }_{18} 294$ U.S. 511 (1935) (Cardozo). The law forbade sale in New York of milk bought elsewhere at a price lower than that permitted within the state; it was condemned as an effort to shield New York farmers from outside competition. Id. at 522. Cardozo's analogy of a tariff against out-of-state products, id. at 521-22, seemed out of place, for a tariff is discriminatory. Nevertheless, if both states adopted conflicting regulations on this subject, interstate commerce could be stifled entirely. See Currie, First Hundred Years at 337-42 (cited in note 13), discussing the Case of the State Freight Tax, 82 U.S. 232 (1873).

Other decisions of the mid-thirties reaffirmed congressional power both to remove the commerce clause barrier to state legislation and to make interstate transportation of goods contrary to state law a federal crime. Whitfield v. Ohio, 297 U.S. 431 (1936) (Sutherland), and Kentucky Whip \& Collar Co. v. Illinois Central R.R., 299 U.S. 334 (1937) (Hughes) (both involving prison-made goods). For earlier precedents, see Currie, 52 U. Chi. L. Rev. at 361-62 (cited in note 13); Currie, 1985 Duke L. J. at 1144 n.167 (cited in note 2); Currie, 1986 Duke L. J. at 112-20 (cited in note 1). For contemporaneous commentary, see J. A. C. Grant, State Power to Prohibit Interstate Commerce, 26 Cal. L. Rev. 34 (1937).

${ }_{183}$ New York ex rel. Rogers v. Graves, 299 U.S. 401 (1937) (Sutherland) (employee of Panama Rail Road, operated as adjunct to Panama Canal, exempt from state income tax); Brush v. Commissioner, 300 U.S. 352 (1937) (Sutherland, over dissents of Brandeis and Roberts) (employee of city water bureau exempt from federal income tax). Contrast South Carolina v. United States, 199 U.S. 437, 458, 463 (1905) (allowing federal tax on state liquor sales). At the same time, declaring it immaterial whether the activity regulated was governmental or proprietary, the Court unanimously held that Congress could require automatic couplers on a state-owned railroad. United States v. California, 297 U.S. 175, 183-85 (1936) (Stone). In the converse situation; the Court had sensibly recognized that state regulation was as great a threat to federal autonomy as was state taxation. See Johnson v. Maryland, 254 U.S. 51 (1920) (state may not require license for post office driver).

${ }^{106}$ Ashton v. Cameron County Water Improv. Dist., 298 U.S. 513 (1936) (McReynolds, over four apt dissents). Contrast Clark v. Barnard, 108 U.S. 436, 447-48 (1883) (state's eleventh amendment immunity from suit "a personal privilege which it may waive at pleasure"), discussed in Currie, First Hundred Years at $427 \mathrm{n.163}$ (cited in note 13); Lincoln County v. Luning, 133 U.S. 529 (1890) (county not "state" within eleventh amendment); United States 
By 1937 it was abundantly clear that the measures that many people believed necessary for economic recovery would not survive Supreme Court scrutiny. It was at this point that President Roosevelt decided to destroy the Court.

\section{A Great Light}

On February 5, 1937, the president announced his proposal to enlarge the Court to fifteen members. Although he coated the pill with unconvincing arguments about the inefficiency of elderly justices, he made no secret of his real purpose: to pack the Court with judges more sympathetic to his legislative program. ${ }^{167}$

Had he succeeded, the Court would never have been the same. Recognition of the legitimacy of diluting the votes of obstructive justices would have severely weakened the Court's ability to enforce the Constitution against other branches, which ever since Marbury v. Madison had been accepted as one of its principal functions. ${ }^{168}$

v. California, 297 U.S. 175 (1936) (suggesting intergovernmental immunity is no limit on commerce power). See the sensible criticism in Harold Gill Reuschlein, Municipal Debt Readjustment: Present Relief and Future Policy, 23 Cornell L. Q. 365, 373-82 (1938); Fraenkel, $85 \mathrm{U}$. Pa. L. Rev. at 38 (cited in note 131) (terming Ashton "as clear a case of judicial legislation as has taken place in a long time").

${ }^{107}$ The bill provided for appointing one new judge for each member of the Court who had reached the age of seventy, had sat for ten years, and had neither resigned nor retired within six months thereafter. S.1392, 75th Cong., 1st Sess. (1937). Six of the nine justices met these criteria when the bill was introduced. Reorganization of the Federal Judiciary, Sen. Rep. No. 711, 75th Cong., 1st Sess. 11 (June 7, 1937). Roosevelt explained his purpose in an address on March 9: "the majority of the Court has been assuming the power to pass on the wisdom of . . . acts of the Congress. . . . [W]e must take action to save the Constitution from the Court." 81 Cong. Rec. Appen. pt. 9 at 469, 470. See generally Robert H. Jackson, The Struggle for Judicial Supremacy (1941); William E. Leuchtenburg, The Origins of Franklin D. Roosevelt's “Court-Packing” Plan, 1966 S.Ct. Rev. 347; Gunther, Constitutional Law at 129-30 (cited in note 72). Others more appropriately suggested a constitutional convention to increase federal power. See, for example, Charles Grove Haines, Judicial Review of Acts of Congress and the Need for Constitutional Reform, 45 Yale L. J. 816 (1936). See also Joseph L. Levinson, Limiting Judicial Review By Act of Congress, 23 Cal. L. Rev. 591 (1935) (advocating statutory requirement of extraordinary majority to invalidate federal statutes under congressional power to make "exceptions" or "regulations" respecting the Court's appellate jurisdiction); D. O. McGovney, Reorganization of the Supreme Court, 25 Cal. L. Rev. 389 (1937) (supporting the packing plan). For a serious proposal to deal by constitutional amendment with the sometimes acute problem of justices who had lost their mental capacity, see Charles Fairman, The Retirement of Federal Judges, 51 Harv. L. Rev. 397 (1938).

196 See McCloskey, The American Supreme Court at 169 (cited in note 7), arguing that passage of the packing plan "would set a precedent from which the institution of judicial review might never recover. . . . [T]he ambiguous and delicately balanced American tradition of limited government was mortally endangered by this bill." Hughes himself is said to have declared that were the bill to pass, "it would destroy the [C]ourt as an institution." See 
Happily, it never came to that, for the Court dramatically changed its course. The packing plan died of supererogation. Unhappily, the price of judicial independence was the death of our federal system.

\section{A. The End of Federalism}

On March 29, 1937, less than two months after the president had announced his packing plan and less than a year after Morehead had reaffirmed the unconstitutionality of minimum wage laws, West Coast Hotel Co. v. Parrish reached the opposite conclusion. ${ }^{168}$ Once again the vote was five to four. The difference was attributable to Justice Roberts, who silently joined the majority in both cases.

The common perception that this was the crucial change of heart that saved the Court seems erroneous. To begin with, the critical vote in Parrish had been taken before the packing plan was made public; unless there was a leak, the decision does not even seem to have been a response to the proposal. ${ }^{130}$ Second, it was not clear that Roberts had actually changed his mind. Parrish overruled Adkins v. Children's Hospital, which had established the general principle that minimum wage laws were unconstitutional;

Pusey, 2 Charles Evans Hughes at 755 (cited in note 2). Even Stone, who had excoriated the Court for its excesses in Butler, wrote privately that the president's "proposal [wa]s too high a price to pay for the correction of some decisions of the Court which I, in common with a great many others, think unfortunate." See Mason, Harlan Fiske Stone at 449 (cited in note 12). See also the admirable answer to Roosevelt's proposal in Sen. Rep. No. 711 at 23 (cited in note 167) ("a measure which should be so emphatically rejected that its parallel will never again be presented to the free representatives of the free people of America"); Alpheus Thomas Mason, Politics and the Supreme Court: President Roosevelt's Proposal, $85 \mathrm{U}$. Pa. L. Rev. 659, 676 (1937) (urging instead an amendment to allow Congress by twothirds vote to override Supreme Court decisions); Currie, First Hundred Years at 66-74, 304-07 (cited in note 13), discussing Marbury v. Madison, 5 U.S. 137 (1803), and Ex parte McCardle, 74 U.S. 506 (1869).

${ }^{180} 300$ U.S. 379 (1937) (Hughes), finding the statute an admissible means for promoting both "the health of women and their protection from unscrupulous and overreaching employers" and noting-in evident response to the argument that employers should not be made to bear the burden-that " '[i]t is safe to assume that women will not be employed at even the lowest wages allowed unless they earn them.' "Id. at 397-98, quoting Holmes's Adkins dissent. The argument of sex discrimination was rejected summarily: women's "relative need in the presence of the evil, no less than the existence of the evil itself, is a matter for the legislative judgment." Id. at 400.

170 See Felix Frankfurter, Mr. Justice Roberts, 104 U. Pa. L. Rev. 311 (1955) (quoting a memorandum left by Roberts); Pusey, 2 Charles Evans Hughes at 757 (cited in note 2), adding that Hughes himself later insisted that "[t]he President's proposal had not the slightest effect on our decision." On the secrecy surrounding the proposal, see Leuchtenburg, 1966 S.Ct. Rev. at 396 (cited in note 167). 
Morehead had carefully said the question of overruling Adkins was not before the Court. ${ }^{171}$ Finally, due process had never been at the center of the Court's disagreement with the New Deal; until the Court receded from its restrictive interpretation of federal power, the president's program remained in mortal peril.

The real breakthrough came on April 12, when in three companion cases the Court by the same five to four vote upheld the National Labor Relations Act provision protecting the right of employees not engaged in interstate or foreign commerce to organize for purposes of collective bargaining. The Court took the easiest case first: Labor Board v. Jones \& Laughlin, which involved a giant steelmaker that obtained its ores from other states and shipped 75 percent of its products in interstate commerce. ${ }^{172}$

The author was Hughes, and the rationale was that which he had enunciated in Shreveport and Schechter: the commerce power "may be exerted to protect interstate commerce 'no matter what the source of the dangers which threaten it.' "173 As the Court recently had held in upholding similar provisions for railroad workers, "the right of employees to self-organization . . . [was] often an essential condition of industrial peace."174 Though manufacturing was not itself commerce, "the stoppage of . . . [Jones \& Laughlin's] operations by industrial strife would have a most serious effect upon interstate commerce"; congressional protection of the right to organize was "necessary to protect interstate commerce from the paralyzing consequences of industrial war."175

Given the established test Hughes employed, this answer was hard to avoid. As he pointed out, an organizing strike at Jones \& Laughlin could have had a "catastrophic" impact on interstate commerce in steel. ${ }^{178} \mathrm{~A}$ similar argument had been rejected in

${ }^{171}$ See 300 U.S. at 389. See also Powell, Vagaries and Varieties at $81 \mathrm{n} .89$ (cited in note 52): “Mr. Justice Roberts's position in the two cases can be harmonized as the view of one who was unable to distinguish the Adkins case but who would accept an opportunity to overrule it." Indeed, Parrish seemed more in line with Roberts's views on related issues than did Morehead. See notes 13-33 and accompanying text, discussing, among others, Nebbia v. New York, 291 U.S. 502 (1934); Pusey, Charles Evans Hughes at 771 (cited in note 2); Frankfurter, $104 \mathrm{U}$. Pa. L. Rev. at 314-15 (cited in note 170) (quoting the Roberts memorandum).

172301 U.S. 1, 25-28 (1937).

173 Id. at 37.

174 Id. at 42. See Texas \& N.O.R.R. Co. v. Clerks, 281 U.S. 548 (1930) (Hughes); Virginian Ry. v. System Federation, 300 U.S. 515 (1937) (Stone).

173 Jones \& Laughlin, 301 U.S. at 41.

${ }^{176}$ Id. at 41 . See also id. at 42 ("[O]f what avail is it to protect the facility of transportation, if interstate commerce is throttled with respect to the commodities to be transported!"). McReynolds, who wrote the usual dissent, protested that a strike was not inevita- 
Carter, however, on the ground that this impact was "indirect."177 One of the companion cases, moreover, cited Jones \& Laughlin without discussion to sustain application of the labor law to a small clothing manufacturer with a minuscule share of the interstate market. ${ }^{178}$ "The business of the Company is so small," McReynolds objected in that case, "that to close its factory would have no direct or material effect upon the volume of interstate commerce in clothing." 179 "That made the case hard to distinguish from Schechter, and thus the case seemed to leave very little beyond the reach of the commerce power. ${ }^{180}$

This time Roberts and Hughes did seem to have changed their minds; but so had Brandeis, Stone, and Cardozo, all of whom had concurred in Schechter. ${ }^{181}$ The dissenters had been deftly hoisted by their own petard, for it was Sutherland in the Carter case who had so fatefully insisted that the magnitude of the effect on commerce was immaterial. ${ }^{182}$

ble even in the absence of legislation. Id. at 99. This, however, had been equally true in the railroad cases.

177 Carter, 298 U.S. at 308 (majority opinion), 317 (Hughes, in separate opinion).

${ }^{178}$ Labor Board v. Clothing Co., 301 U.S. 58 (1937) (Hughes). In this case, the company's total sales in the first ten months of 1935 amounted to $\$ 1,750,000$. Id. at 72 . The third case, Labor Board v. Fruehauf Co., 301 U.S. 49 (1937) (Hughes), applied the same reasoning to the country's largest trailer manufacturer.

178 Clothing Co., 301 U.S. at 94 (dissent).

180 See id. at 99 (McReymolds, dissenting) ("Almost anything-marriage, birth, deathmay in some fashion affect commerce.") Professor Powell's attempted distinction between pre- and post-commerce activities (Powell, Vagaries and Varieties at 80 (cited in note 52), arguing that Schechter involved "local practices after the interstate transportation was completed, with no future extrastate effect to follow") fails to distinguish the coal mining regulations struck down in Carter, which many thought had sealed the doom of the statute upheld in the Labor Board cases. See, e.g., Stern, 59 Harv. L. Rev. at 676 (cited in note 73); Fraenkel, 85 U. Pa. L. Rev. at 36 (cited in note 127). See also Joseph H. Mueller, Businesses Subject to the National Labor Relations Act, 35 Mich. L. Rev. 1286, 1297 (1937), which maintains that both Schechter and Carter were distinguishable from Jones \& Laughlin because the effect of a work stoppage on commerce was more immediate than the "intricate economic effects of . . . labor costs upon the prices and movement of products in interstate commerce" " (quoting from the government's brief in Jones \& Laughlin). But this argument had been made and rejected in Carter.

18I The usually tolerant Brandeis reputedly told Thomas Corcoran on the day Schechter was decided: "This is the end of this business of centralization, and I want you to go back and tell the President that we're not going to let this government centralize everything." See Schlesinger, Politics of Upheaval at 280 (cited in note 130).

${ }^{182}$ The Court expressly confirmed that in Labor Board v. Fainblatt, 306 U.S. 601, 606 (1939) (Stone), involving yet another small clothing manufacturer: "[t]he power of Congress to regulate interstate commerce . . . extends to all such commerce be it great or small." With Van Devanter and Sutherland gone, only McReynolds and Butler remained to protest that, as construed by the Court, the commerce power "brings within the ambit of federal control most if not all activities of the Nation" and that "[i]f the possibility of this had been declared the Constitution could not have been adopted." Id. at 610 . 
Other decisions confirmed that the game was over. Helvering $v$. Davis demonstrated the breadth of Butler's concession that Congress could spend for any nationwide purpose by upholding the old-age benefits provided through Social Security. ${ }^{183}$ Steward $M a-$ chine Co. v. Davis suggested that Butler and Carter had lost much of their restrictive force by sustaining a federal tax plainly designed to induce states to provide unemployment insurance. ${ }^{184}$ United States v. Darby ${ }^{\mathbf{1 8 5}}$ explicitly overruled Hammer $v$. Dagenhart in holding that Congress could exclude from interstate commerce goods made by employees paid less than a specified wage and also drove yet another nail into Schechter's coffin by upholding federal minimum wages for employees engaged in production. Not only did the latter provision, in Stone's view, protect against the adverse effects of low wages on interstate commerce; it was also sustainable on the more sweeping ground that it helped to effectuate the exclusion from interstate trade. ${ }^{186}$

It was shortly after Hughes's retirement that Wickard $v$. Filburn permitted Congress to limit the wheat a farmer grew for his own consumption on the ground that what he could not grow he might buy from another state. ${ }^{187}$ But that was only to write the

195301 U.S. 619 (1937) (Cardozo, over dissents by McReynolds and Butler).

1* Steward Machine Co. v. Davis, 301 U.S. 548 (1937) (Cardozo, over four dissents). The law gave a 90 percent credit for contributions made to an unemployment fund under state law. Id. at 574. As the Court noted, there was no contract in Steward, id. at 592; but the arrangement was no less coercive as a result. Even Sutherland, however, did not argue that states were coerced into establishing the unemployment fund. See id. at 610 . See also Sonzinsky v. United States, 300 U.S. 506, 514 (1937) (Stone), unanimously upholding a $\$ 200$ annual tax on dealers in such firearms as machine guns and sawed-off shotguns: "[Courts] will not undertake, by collateral inquiry as to the measure of the regulatory effect of a tax, to ascribe to Congress an attempt, under the guise of taxation, to exercise another power denied by the Federal Constitution." This case closely resembles Constantine, 296 U.S. 287 (1935), in all save the result; Professor Powell in Vagaries and Varieties at 87 (cited in note 52) termed it "[h]ardly candid."

18s 312 U.S. 100, 115 (1941) (Stone).

186 "Congress, having . . . adopted the policy of excluding from interstate commerce all goods ... which do not conform to the specified labor standards, . . . may choose the means reasonably adapted to the attainment of the permitted end, even though they involve control of intrastate activities." 312 U.S. at 121. Gunther suggests that if this "superbootstrap" argument were taken at face value, congressional "regulation of local activities . . . [could] now be justified without any showing of the impact of the local activity on commerce-simply by having the regulatory scheme include a ban on interstate shipments, and then justifying the regulation as a means to effectuate that 'commerce-prohibiting' sanction." Gunther, Constitutional Law at 143-44 (cited in note 72). The tenth amendment, Stone correctly emphasized, "states but a truism that all is retained which has not been surrendered." Darby, 312 U.S. at 124. The decision was unanimous, having been rendered two days after the retirement of Justice McReymolds, the last of the old guard.

${ }_{187} 317$ U.S. 111 (1942) (Jackson). The Court rejected the distinction between direct and indirect effects, holding it irrelevant that "appellee's own ... demand for wheat may 
epitaph; constitutional federalism had died in 1937.

\section{B. Other Limitations}

Federalism was not the only victim of the judicial New Deal. Other longstanding constitutional limitations also underwent momentous changes. ${ }^{188}$

The decline of economic due process heralded by Parrish continued with the overruling of decisions striking down bans on yellow dog contracts and regulation of employment agency fees. ${ }^{189} \mathrm{~A}$ state was allowed to legalize peaceful picketing despite the due process and equal protection implications of Truax v. Corrigan. ${ }^{190}$ In sustaining a ban on interstate shipment of "filled" milk, the famous Carolene Products opinion enunciated a "rational basis" test that raised doubts whether any economic regulation would be held to offend due process on substantive grounds. ${ }^{181}$ Olsen $v$. Nebraska

be trivial by itself . . . where, as here, his contribution, taken together with that of many others similarly situated, is far from trivial." Id. at 127-28. There was no one left to dissent. When subsidies for the same purpose were struck down in Butler, no one had even argued that Congress could directly impose production quotas under the commerce power. See McCloskey, The American Supreme Court at 185 (cited in note 7): "It was now evident that Congress could reach just about any commercial subject it might want to reach and could do to that subject just about anything it was likely to want to do." Professor Powell in Vagaries and Varieties at 83-84 (cited in note 52) called Wickard "an able latitudinarian opinion" by which "formalism has been succeeded by plain common sense" and concluded that "[h]appily . . . the Framers were wise enough . . . to leave room for the judgments of their successors" when drafting the commerce clause. See also the approving comments of Stern, 59 Harv. L. Rev. at 908-09 (cited in note 73).

${ }^{183}$ See Osmond K. Fraenkel, Constitutional Issues in the Supreme Court, 1937 Term, 87 U. Pa. L. Rev. 50, 50 (1938): "The 1937 Term is distinguished . . . by the large number of cases in which the Court reversed earlier positions."

${ }^{189}$ Phelps Dodge Corp. v. Labor Board, 313 U.S. 177, 187 (1941) (Frankfurter), confirming the demise of Adair v. United States, 208 U.S. 161 (1908), and of Coppage v. Kansas, 236 U.S. 1 (1915); Olsen v. Nebraska, 313 U.S. 236, 244 (1941) (Douglas), overruling Ribnik v. McBride, 277 U.S. 350 (1928). Compare Wright v. Vinton Branch, 300 U.S. 440 (1937) (Brandeis) (unanimously upholding a revised federal law for the relief of insolvent farmers), with Louisville Bank v. Radford, 295 U.S. 555 (1935).

190 Senn v. Tile Layers Union, 301 U.S. 468, 479-80 (1937) (Brandeis, over four dissents), distinguishing Truax v. Corrigan, 257 U.S. 312 (1921), on the ground that the picketing in that case had not been peaceful. Indeed, the Court would soon hold in Thornhill v. Alabama, 310 U.S. 88 (1940) (Murphy), that peaceful picketing was protected by freedom of expression from state abridgement.

101 United States v. Carolene Products Co., 304 U.S. 144, 152 (1938) (Stone, speaking at this point for four justices) (" $[R]$ egulatory legislation affecting ordinary commercial transactions is not to be pronounced unconstitutional unless in the light of the facts made known or generally assumed it is of such a character as to preclude the assumption that it rests upon some rational basis within the knowledge and experience of the legislators."). A fifth vote for the result was cast by Justice Black, who had already advanced the startling conclusion that corporations were not "persons" within the fourteenth amendment at all. Connecticut General Co. v. Johnson, 303 U.S. 77, 85 (1938) (dissenting opinion). See Mc- 
fueled those doubts by declaring that "the only constitutional prohibitions or restraints which respondents have suggested for the invalidation of this legislation are those notions of public policy embedded in earlier decisions of this Court but which, as Mr. Justice Holmes long admonished, should not be read into the Constitution."182

Other equal protection landmarks fell, and the recently exhumed privileges or immunities clause of the fourteenth amendment was reburied when the Court sustained an agricultural exemption from antitrust regulation and upheld a state statute that discriminated against out-of-state deposits. ${ }^{193}$ Further inroads were made on the contract clause by allowing states retroactively to limit both deficiency judgments and savings withdrawals. ${ }^{194}$ What

Closkey, The American Supreme Court at 186 (cited in note 7): "It is hard to conceive a law so patently unreasonable that it would fail under [the Carolene Products] test, and it is therefore not surprising that the Court since 1937 has never encountered one."

The statute defined "filled milk" as skimmed milk "compounded with . . . any fat or oil other than milk fat"-in this case, with coconut oil. 304 U.S. 144, 145 n.1 (1938). A similar state law had been upheld in less tolerant days in Hebe Co. v. Shaw, 248 U.S. 297 (1919) (Holmes, over three dissents on statutory grounds). See also Powell v. Pennsylvania, 127 U.S. 678 (1888) (upholding ban on sale of oleomargarine), discussed in Currie, First Hundred Years at 377-78 (cited in note 13). The most serious argument in favor of the law upheld in Carolene was that because crucial vitamins were removed with the butter fat, children drinking only filled milk might suffer undernourishment and consequent disease. See 304 U.S. at 149 n.2. But the Court subsequently sustained application of the law even after the manufacturer remedied this deficiency by adding vitamins, because it was "disputable" whether labeling requirements would counter the risk of confusion. Carolene Products Co. v. U.S., 323 U.S. 18, 22-23, 29 (1944) (Reed, for a unanimous Court).

${ }^{192} 313$ U.S. 236, 246-47 (1941) (Dougles) (upholding state statute limiting fees charged by private employment agencies). See Robert G. McCloskey, Economic Due Process and the Supreme Court: An Exhumation and Reburial, 1962 S.Ct. Rev. 34, 36-40.

193 Tigner v. Texas, 310 U.S. 141 (1940) (Frankfurter, over one of McReynolds's last dissents), overruling Connolly v. Union Sewer Pipe Co., 184 U.S. 540 (1902); Madden v. Kentucky, 309 U.S. 83, $92-93$ (1940) (Reed, over dissents by McReynolds and Roberts) ("We think it quite clear that the right to carry out an incident to a trade, business or calling such as the deposit of money in banks is not a privilege of national citizenship."), overruling Colgate v. Harvey, 296 U.S. 404 (1935)).

194 Honeyman v. Jacobs, 306 U.S. 539, 542 (1939) (Hughes) (stressing that the statute abrogated the right to seek a deficiency judgment only if the value of the land sold at foreclosure had equaled the outstanding debt: "The contract contemplated that the mortgagee should make himself whole, if necessary, out of the security but not that he should be enriched at the expense of the debtor."); Veix v. Sixth Ward Ass'n, 310 U.S. 32 (1940) (Reed). Earlier cases had held that laws suspending contract rights had to be limited to the emergency that necessitated them. See, e.g., W.B. Worthen Co. v. Thomas, 292 U.S. 426, 432 (1934). Veix held it irrelevant that the limit on savings withdrawals was "permanent." See 310 U.S. at 39-40. See also Robert L. Hale, The Supreme Court and the Contract Clause: I, 57 Harv. L. Rev. 512, 548-51 (1944) (explaining that the law upheld in Honeyman was "designed to prevent a party from getting more by way of remedy than he would get by performance"). 
looked like a delegation of legislative power to private parties was upheld without so much as a reference to Carter. ${ }^{195}$ Under the deft leadership of Justice Stone, moreover, the Court made drastic revisions in three other areas involving the operation of the federal system. ${ }^{198}$

In the field of intergovernmental immunity, the Court retreated from its recent conclusion that local governments could not be permitted to invoke the protection of bankruptcy. ${ }^{197}$ It departed from other precedents as well in allowing the taxation of government contractors and governmental salaries. ${ }^{198}$ At least where the burden on government was only indirect, the Court of the late 1930s seemed disinclined to treat the power to tax as the power to destroy unless it was discriminatorily applied. ${ }^{198}$

${ }^{188}$ United States v. Rock Royal Co-op, 307 U.S. 533, 577-78 (1939) (Reed) (upholding provision for milk marketing orders to be effective upon approval by two thirds of producers, on the unconvincing ground that "Congress had the power to put this Order into effect without the approval of anyone"). See Louis L. Jaffe, Law Making by Private Groups, 51 Harv. L. Rev. 201 (1937), for sobering examples of the prevalence of private "lawmaking," from collective bargaining agreements to professional standards to rules of stock exchanges and political parties. The delegation of authority to the secretary of agriculture to determine the terms of such an order, which the Court also upheld, was fully consistent with the criteria laid down in Schechter; for the statute required him, in the Court's words, essentially to establish "the prices that will give the commodity a purchasing power equivalent to that of the base period, considering the price and supply of feed and other pertinent economic conditions affecting the milk market in the area." 307 U.S. at 577.

${ }^{108}$ See Noel T. Dowling, Elliott E. Cheatham, and Robert L. Hale, Mr. Justice Stone and the Constitution, 36 Colum. L. Rev. 351 (1936).

187 United States v. Bekins, 304 U.S. 27 (1938) (Hughes, over two dissents), overruling Ashton v. Cameron County Water Improv. Dist., 298 U.S. 513 (1936).

${ }_{183}$ James v. Dravo Contracting Co., 302 U.S. 134, 149-61 (1937) (Hughes, over dissents by Roberts, McReynolds, Sutherland, and Butler after Van Devanter had retired), disapproving Panhandle Oil Co. v. Knox, 277 U.S. 218 (1928); Helvering v. Gerhardt, 304 U.S. 405 (1938) (Stone, over two dissents), limiting The Collector v. Day, 78 U.S. (11 Wall.) 113 (1871); Graves v. New York ex rel. O'Keefe, 306 U.S. 466 (1939) (Stone, over two dissents), overruling both Day and New York ex rel. Rogers v. Graves, 299 U.S. 401 (1937); Helvering v. Mountain Producers Corp., 303 U.S. 376 (1938) (Hughes), overruling Burnet v. Coronado Oil \& Gas Co., 285 U.S. 393 (1932), and Gillespie v. Oklahoma, 257 U.S. 501 (1922), in broadening the ability of Congress to tax state oil lessees. See also O'Malley v. Woodrough, 307 U.S. 277, 282 (1939) (Frankfurter, over Butler's dissent), permitting Congress to tax the salaries of federal judges appointed after the tax law was passed and casting doubt on Evans v. Gore, 253 U.S. 245 (1920), which had forbidden taxation of previously appointed judges whose compensation was expressly protected against diminution by article III. See generally Charles L. B. Lowndes, Taxation and the Supreme Court, 1937 Term, 87 U. Pa. L. Rev. 1, 215 (1938); Powell, Vagaries and Varieties at 122 (cited in note 52), criticizing Dravo on the ground that "[f]rom an economic standpoint it makes no difference whether the tax is imposed on the seller or on the buyer, on the builder or on his patron."

189 "I have always felt," wrote Stone privately in 1937, "that everything needful would have been accomplished had Marshall merely declared that neither government can adopt a tax which discriminates against the other." Letter to Irving Brant, May 1, 1937, quoted in Mason, Harlan Fiske Stone at 503 (cited in note 12). See also Currie, First Hundred Years 
A similar philosophy underlay Justice Stone's equally creative conclusion that the commerce clause precluded essentially only those state laws discriminating against interstate commerce or subjecting it to multiple burdens. ${ }^{200}$ Like the federal and state governments in the field of immunity, interstate commerce was not in his view entitled to special privileges; it was enough that it not be subjected to special burdens. ${ }^{201}$

No less revolutionary was Justice Stone's reformulation of the geographical limitations that the Court had found both due process and full faith and credit to impose on state power to tax or

at $165-68$ (cited in note 13), discussing McCulloch, 17 U.S. 316.

${ }^{200}$ See, e.g., South Carolina State Highway Dept. v. Barnwell Bros., 303 U.S. 177 (1938) (Stone) (upholding state law limiting width and weight of trucks as safety measure despite serious effect on commerce); Western Live Stock v. Bureau of Revenue, 303 U.S. 250 (1938) (Stone) (upholding tax measured by gross receipts no other state could tax); McGoldrick v. Berwind-White Coal Mining Co., 309 U.S. 33, 69 (1940) (Stone) (upholding sales tax on goods delivered from other states over Hughes's dissent invoking Stone's own multiple burden test: "[i]f New York can tax the delivery, Pennsylvania can tax the shipment and New Jersey the transshipment"); California v. Thompson, 313 U.S. 109 (1941) (Stone) (overruling DiSanto v. Pennsylvania, 273 U.S. 34 (1927), in upholding licensing of agent selling interstate transportation).

See also Henneford v. Silas Mason Co., 300 U.S. 577 (1937) (Cardozo) (upholding compensatory use tax on goods bought outside the state despite analogy of Baldwin v. G.A.F. Seelig, 294 U.S. 511 (1935)); Milk Board v. Eisenberg Co., 306 U.S. 346 (1939) (Roberts) (upholding power to set minimum prices for milk sold for transportation in interstate commerce after Baldwin had removed risk of contradictory law in receiving state). See generally Noel T. Dowling, Interstate Commerce and State Power, 27 Va. L. Rev. 1, 19-20 (1940) (urging a frank balancing of state and federal interests under the rubric of implicit congressional will); Powell, Vagaries and Varieties at chs. 5, 6 (cited in note 52), and especially id. at 167-69 (suggesting by analogy to the original package cases, discussed in Currie, $52 \mathrm{U}$. Chi. L. Rev. at 358-60 (cited in note 13), that Baldwin and Henneford might be reconcilable on the ground that "prohibition is much more of an intrusion on a free national economy than is an equalizing tax"); Ernest J. Brown, The Open Economy: Justice Frankfurter and the Position of the Judiciary, 67 Yale L. J. 219 (1957) (arguing that Stone's emphasis on equality was insufficient to prevent protectionism or exploitation of geographical advantage). Endorsements of Stone's view of multiple taxation include Thomas Reed Powell, New Light on Gross Receipts Taxes, 53 Harv. L. Rev. 909 (1940); William B. Lockhart, State Tax Barriers to Interstate Trade, 53 Harv. L. Rev. 1253 (1940); Stanley Morrison, State Taxation of Interstate Commerce, 36 Ill. L. Rev. 727 (1942).

${ }^{201}$ See Barnwell, 303 U.S. at 184-85 n.2, invoking the virtual representation argument that Marshall had made in distinguishing state and federal taxes in McCulloch, 17 U.S. 316. Stone wrote: "Underlying the stated rule [against discrimination against interstate commerce] has been the thought . . . that when the regulation is of such a character that its burden falls principally upon those without the state, legislative action is not likely to be subjected to those political restraints which are normally exerted on legislation where it affects adversely some interests within the state." The same philosophy seems in part to underlie other provisions assuring that politically weak classes are treated as well as the dominant majority. See, for example, U.S. Const. art. IV, § 2 (citizens of other states entitled to privileges and immunities of local citizens); id. amend. XIV, $\S 1$ (equal protection of the laws). See generally John Hart Ely, Democracy and Distrust 77-88 (1980). 
regulate. What mattered in the tax field was no longer the often fictitious location of intangible property but rather whether the taxpayer could fairly be said to receive protection in return for his money. ${ }^{202}$ Similarly, in choice of law cases Justice Story's territorialist analysis yielded to the requirement that the application of the law in question serve a legitimate state interest. ${ }^{203}$ While this development left unfulfilled the hope that the full faith and credit clause might provide a means of resolving conflicts that interested states could not work out on their own, ${ }^{204}$ some have defended it on the ground that the problem is unfit for judicial resolution. ${ }^{205}$ In any event, the new analysis of state interests seemed more consonant with the constitutional purpose of keeping one state from meddling in another's affairs than did the procrustean rules it supplanted. ${ }^{206}$

${ }^{202}$ See New York ex rel. Cohn v. Graves, 300 U.S. 308 (1937) (Stone, over dissents by Butler and McReynolds) (state may tax income from out-of-state property); First Bank Stock Corp. v. Minnesota, 301 U.S. 234, 240-41 (1937) (Stone) (state of corporation's commercial domicile may tax its shares in foreign corporations); Curry v. McCanless, 307 U.S. 357 (1939) (Stone, over four dissents) (both testator's and trustee's domiciles may tax passage of trust property by will).

${ }^{203}$ Contrast, e.g., Osborn v. Ozlin, 310 U.S. 53 (1940) (Frankfurter, over dissents by Roberts, Hughes, and McReynolds) (upholding requirement that local risks be insured through a local agent, without regard to place contract was made), with Allgeyer v. Louisiana, 165 U.S. 578 (1897) (invalidating requirement that insurer qualify to do business in state before taking action there with respect to insuring local risks). Contrast Pacific Ins. Co. v. Industrial Accident Comm., 306 U.S. 493 (1939) (Stone) (state of injury may apply own workmen's compensation law though employment contract centered elsewhere), with Bradford Elec. Co. v. Clapper, 286 U.S. 145 (1932) (Brandeis) (holding law of the place of employment governed). The way to Pacific Ins. Co. had been cleared in Alaska Packers Ass'n v. Industrial Accident Comm., 294 U.S. 532 (1935), where Stone had employed his novel interest analysis to reaffirm the Clapper conclusion that the state of employment might apply its law as well. Consider also Skiriotes v. Florida, 313 U.S. 69 (1941) (Hughes) (upholding state's right to regulate its citizen's gathering of sponges outside territorial limits). The one decision out of line with other developments in this area was Sovereign Camp of the Woodmen of the World v. Bolin, 305 U.S. 66, 75 (1938) (Roberts) (alternative holding), where in reliance on precedent the Court unanimously held that a policyholder's state could not deny that the terms of an insurance contract were ultra vires, because "the rights of membership [in a fraternal benefit society] are governed by the law of the State of incorporation."

${ }^{204}$ See, for example, Robert H. Jackson, Full Faith and Credit-The Lawyer's Clause of the Constitution, 45 Colum. L. Rev. 1 (1945).

${ }^{205}$ See Brainerd Currie, Selected Essays on the Conflict of Laws ch. 5 (1963).

200 Both the territorialist approach and Justice Stone's approach to full faith and credit depended on the disputable conclusion that the reference to "public Acts" in that clause was meant to require respect for general laws of other states rather than, as explained in the Convention, for quasi-judicial legislation such as individual acts of bankruptcy. See the discussion in Currie, 52 U. Chi. L. Rev. at 885-86 n.117 (cited in note 158). As far as due process was concerned, Stone's interest analysis was a natural corollary of the general requirement that laws be reasonably tailored to accomplish legitimate legislative goals. 
Related to the interstate choice of law cases was the stunning decision in Erie R.R. v. Tompkins, ${ }^{207}$ overruling nearly 100 years of precedent in holding that federal courts must follow state judgemade law as well as state statutes except where the Constitution or federal statutes otherwise required. ${ }^{208}$ That was indeed what the governing statute seemed to modern eyes to say, and recent scholarship had suggested it reflected the original intention as well. ${ }^{209}$ But Justice Brandeis was willing to depart from stare decisis only because he was convinced that the earlier practice was unconstitutional: "Congress has no power to declare substantive rules of common law applicable in a State whether they be local in their nature or 'general,' be they commercial law or a part of the law of torts. And no clause in the Constitution purports to confer such a power upon the federal courts."210

It may seem odd that the Court cut back on federal judicial authority at the same time it so greatly expanded the powers of Congress. Perhaps it was still true, as Brandeis argued, that Congress itself could not regulate everything. After the permissive commerce clause decisions of the preceding year, however, there was certainly a strong argument that Congress could have regulated the liability of interstate railroads to trespassers, and that was what Erie involved. 211

Thus on the facts of the case the more serious objection seemed to be one less of federalism than of separation of powers: whether or not Congress could make rules to govern the particular

207304 U.S. 64 (1938) (Brandeis, over dissents by Butler and McReynolds).

208 The contrary conclusion, with the exception of such "local" matters as those respecting land, had been reached in Swift v. Tyson, 41 U.S. 1 (1842).

${ }_{200}$ See Judiciary Act of Sept. $24,1789, \S 34,1$ Stat. 73,92 , codified at 28 U.S.C. $\S 725$ "[T] $]$ he laws of the several states, except where the constitution, treaties, or statutes of the United States shall otherwise require or provide, shall be regarded as rules of decision in trials at common law in the courts of the United States in cases where they apply"); Charles Warren, New Light on the History of the Federal Judiciary Act of 1789, 37 Harv. L. Rev. 49 (1924). Later observers have been less confident of this conclusion. See William Winslow Crosskey, 1 \& 2 Politics and the Constitution in the History of the United States 626-28, 866-71 (1953); Henry J. Friendly, In Praise of Erie-And of the New Federal Common Law, 39 N.Y.U. L. Rev. 383, 389-91 (1964).

${ }_{210} 304$ U.S. at 78. See John Hart Ely, The Irrepressible Myth of Erie, 87 Harv. L. Rev. 693,703 (1974) (practice under Swift v. Tyson "was unconstitutional because nothing in the Constitution provided the central government with a general lawmaking authority of the sort the Court had been exercising").

${ }^{211}$ See Ely, 87 Harv. L. Rev. at 703 n.62 (cited in note 210); Second Employers' Liability Cases, 223 U.S. 1, 52 (1912) (upholding federal law rendering interstate railroad liable for injuries to employees), discussed in Currie, 1985 Duke L. J. at 1119 (cited in note 2). For lingering doubts on this issue, see Stewart Jay, Origins of Federal Common Law: Part Two, 133 U. Pa. L. Rev. 1231, 1312 \& n.401 (1985). 
case, it had not done so; and the federal courts had only those powers given them by the Constitution or statute. ${ }^{212}$

The grant of admiralty jurisdiction had long been understood to imply authority to fashion federal common law. ${ }^{213}$ Brandeis did not explain why the parallel grant of diversity jurisdiction, which was the basis of the suit in Erie, did not imply such authority as well. ${ }^{214}$ The answer lies in the differing purposes the Court has found to underlie the two jurisdictional provisions: while one reason for the admiralty grant was apparently to permit the development of a uniform maritime law, the purpose of diversity jurisdiction was only to assure out-of-state litigants an impartial forum. ${ }^{215}$ Thus the best explanation of the constitutional holding in Erie

212 Viewed in this light, Erie and the increased tolerance for federal legislation were wholly consistent manifestations of a general tendency toward restraint in the exercise of federal judicial authority.

${ }^{213}$ See The Lottawanna, 88 U.S. 558, 574-75 (1875), discussed in Currie, First Hundred Years at 404 n.4 (cited in note 13); Southern Pacific Co. v. Jensen, 244 U.S. 205, 215 (1917) ("II]n the absence of some controlling statute the general maritime law as accepted by the federal courts constitutes part of our national law."), discussed in Currie, 1985 Duke L. J. at $1139-45$ (cited in note 2).

${ }^{214}$ See Charles T. McCormick and Elvin Hale Hewins, The Collapse of "General" Law in the Federal Courts, 33 Ill. L. Rev. 126, 135, 141 (1938). This contrast was heightened by Brandeis's unexplained conclusion, the very day Erie was decided, that "whether the water of an interstate stream must be apportioned between the two States is a question of 'federal common law' upon which neither the statutes nor the decisions of either State can be conclusive." Hinderlider v. La Plata River \& Cherry Creek Ditch Co., 304 U.S. 92, 110 (1938).

${ }^{215}$ See Martha A. Field, Sources of Law: The Scope of Federal Common Law, 99 Harv. L. Rev. 881, 915-18 (1986). See also Knickerbocker Ice Co. v. Stewart, 253 U.S. 149, 160 (1920) ("To preserve adequate harmony and appropriate uniform rules relating to maritime matters and bring them within control of the Federal Government was the fundamental purpose [of the admiralty clause]."); David P. Currie, Federalism and the Admiralty: "The Devil's Own Mess," 1960 S.Ct. Rev. 158, 158-64; Bank of the United States v. Deveaux, 9 U.S. 61, 87 (1809) (attributing diversity jurisdiction to "apprehensions" that state courts might not "administer justice . . . impartially" in cases involving outsiders). Justice Brandeis reaffirmed this understanding of diversity jurisdiction elsewhere in the Erie opinion. 304 U.S. at 74.

The citation in Hinderlider, 304 U.S. at 110, to Kansas v. Colorado, 206 U.S. 46, 98 (1907), helps to explain the contrast between Hinderlider and Erie. Kansas was a controversy between states. Since to apply the law of either state in such a case would make one party the judge in its own cause, the jurisdictional grant of jurisdiction over controversies between states has also been held to confer federal common law authority. See Texas v. New Jersey, 379 U.S. 674, 677 (1965); Friendly, 39 N.Y.U. L. Rev. at 383, 394-98 (cited in note 209). Hinderlider was not itself an interstate suit, but the federal common law developed in such suits is supreme and thus applicable in other cases as well. Compare Pope \& Talbot, Inc. v. Hawn, 346 U.S. 406, 411 (1953) (holding federal maritime law governed in diversity case).

For the argument that no grant of judicial power in article III was meant to embrace lawmaking authority, see Edward S. Stimson, Swift v. Tyson-What Remains?, 24 Cornell L. Q. 54, 60-64 (1938) (invoking an earlier draft conveying "jurisdiction" rather than "judicial power"). 
is that, like a state court that has no significant contacts with the matter in controversy, a federal court sitting solely in diversity is a disinterested forum with respect to the merits; and as Justice Stone made clear in the interstate choice of law cases, only an interested forum can apply its own law. ${ }^{216}$

\section{Conclusion}

The Constitution was very different at the end of Hughes's tenure than at the beginning. The retreat of substantive due process in economic cases was a blessing; the doctrine had been illegitimate from the start. In rewriting the contract clause and eradicating federalistic limitations on national authority, however, the Court seemed to embrace the dangerous principle that constitutional provisions that did not suit contemporary needs need not be respected.

All nine justices voted to enforce the limitation on congressional power in Schechter; two years later five of them voted to ignore it. Why? Had the Court-packing proposal frightened them into making a tactical concession to avoid the greater evil? ${ }^{217} \mathrm{Had}$ circumstances or public opinion persuaded them that the need for a stronger central government justified taking liberties with the Constitution? ${ }^{218}$ Had repeated encounters with refractory factual situations convinced them that there was no tenable place to draw the line? Answers to questions like these are not to be found in judicial opinions.

216 That a forum with no interest in the merits may have legitimate interests in its own procedure helps to explain how the Court could so easily dismiss possible constitutional objections to the Federal Rules of Civil Procedure after Erie. See Sibbach v. Wilson \& Co., 312 U.S. 1, 9-10 (1941). For decisions upholding state procedural requirements in related contexts see Wells v. Simonds Abrasive Co., 345 U.S. 514 (1953) (allowing state court to dismiss action based on foreign law in reliance on local statute of limitations); Missouri ex rel. Southern Ry. Co. v. Mayfield, 340 U.S. 1 (1950) (allowing state court to dismiss FELA action on grounds of forum non conveniens).

217 See, e.g., Rodell, Nine Men at 250 (cited in note 6): "with childlike clarity, the citizen saw that the Court had nakedly succumbed to political pressure." Chief Justice Hughes denied not only that the packing plan had any effect, but also that he had ever changed his mind. His biographer rosily attributes the apparent switch in judicial attitude to increased congressional restraint. See Pusey, 2 Charles Evans Hughes at 768, 771 (cited in note 2).

218 See Corwin, Constitutional Revolution, Ltd. at 73 (cited in note 11), invoking the 1936 election and industrial unrest. Justice Roberts himself pointed to the coercive effect of public opinion: "it is difficult to see how the Court could have resisted the popular urge for uniform standards . . . for what in effect was a uniform economy. . . . An insistence by the Court on holding federal power to what seemed its appropriate orbit when the Constitution was adopted might have resulted in even more radical changes." Owen Josephus Roberts, The Courts and the Constitution 61-62 (1951). See also McCloskey, The American Supreme Court at 225 (cited in note 7) ("history, not the Court, made this decision"). 
The revolution was often explained in terms of Justice Holmes's familiar argument of judicial restraint. ${ }^{219}$ In cases involving "ordinary commercial transactions," wrote Justice Stone in the Carolene Products case, "in the absence of statutory findings" supporting the legislative judgment "they would be presumed."220 This was the deferential approach Brandeis had employed in upholding limits on insurance commissions in $1931,{ }^{221}$ suggesting both a respect for the opinions of other branches and what Judge Cooley had referred to as "conscious[ness] of the fallibility of the human judgment."222 Similar considerations underlay Brandeis's familiar list in the Ashwander case of judicially created doctrines for avoiding the decision of constitutional questions entirely. ${ }^{223}$

Other decisions, however, contained little hint of deference to legislative determinations. Both Parrish and the Labor Board cases, like Roberts's earlier opinion upholding graduated chain store taxes, ${ }^{224}$ ringingly endorsed the reasonableness of the legislative decision, while the opinion sustaining regulation of employment agency fees cast doubt on the concept of substantive due process itself. ${ }^{225}$ It may well be that on average the justices of the late 1930 s took a more modest view of the judicial function than some of their predecessors; but they pretty clearly also had a different view of the substantive provisions they were construing.

Appropriately, it was Justice Stone-perhaps the principal architect of the whole revolution-who summed it all up in the most clairvoyant and best-known footnote in Supreme Court history. No longer would the Court be much concerned with the controversies

219 See, e.g., Lochner v. New York, 198 U.S. 45, 74-76 (1905) (dissent); F. D. G. Ribble, Some Aspects of Judicial Self-Restraint, 26 Va. L. Rev. 981 (1940).

220304 U.S. at 152-53.

221 O'Gorman and Young v. Hartfield Ins. Co., 282 U.S. 251 (1931).

222 Thomas M. Cooley, 1 Constitutional Limitations 332 (8th ed. 1927).

${ }^{223}$ Ashwander, 297 U.S. at 345-48 (concurrence), quoting Cooley, Constitutional Limitations at 232 (cited in note 222). See also Coleman v. Miller, 307 U.S. 433 (1939), where over the dissents of Butler and McReynolds the Court refused to decide whether a state could ratify a proposed constitutional amendment after rejecting it and whether it could be ratified thirteen years after its proposal. Three justices concluded that article V confided the decision of both questions exclusively to Congress; four others thought this was true of the entire amendment process and argued with much force that state legislators who had voted against the amendment had no standing to sue. For criticism of this decision, see Walter Dellinger, The Legitimacy of Constitutional Change: Rethinking the Amendment Process, 97 Harv. L. Rev. 386, 397-98, 411 (1983): "Neither the text of the Constitution nor prior congressional practice nor judicial precedent supports this bestowal of exclusive power on Congress."

${ }^{224}$ Tax Commissioners v. Jackson, 283 U.S. 527 (1931).

225 Olsen v. Nebraska, 313 U.S. 236 (1941). 
over social and economic legislation that had commanded the bulk of its past attention. In suggesting that the presumption of constitutionality might have less force with respect to measures affecting specific guarantees like freedom of speech, disadvantaging "discrete and insular minorities," or obstructing "those political processes which can ordinarily be expected to bring about repeal of undesirable legislation," Stone established the Court's agenda for the next fifty years. ${ }^{228}$

${ }^{228}$ Carolene Products, 304 at 152-53 n.4. See also McCloskey, The American Supreme Court at 177-79 (cited in note 7); Paul L. Murphy, The Constitution in Crisis Times, 1918 1969 at 169 (1972). 